\title{
CARACTERIZAÇÃO CLÍNICA, RADIOGRÁFICA E MOLECULAR DA SÍNDROME DE VAN DER WOUDE
}

Carlos Henrique Bettoni Cruz de Castro

Dissertação apresentada à Faculdade de Odontologia de Bauru, Universidade de São Paulo, como parte dos requisitos para a obtenção do título de Mestre em Odontologia, área de concentração Patologia Bucal. 


\section{CARACTERIZAÇÃO CLÍNICA, RADIOGRÁFICA E MOLECULAR DA SÍNDROME DE VAN DER WOUDE}

\section{Carlos Henrique Bettoni Cruz de Castro}

Dissertação apresentada à Faculdade de Odontologia de Bauru, Universidade de São Paulo, como parte dos requisitos para a obtenção do título de Mestre em Odontologia, área de concentração Patologia Bucal.

Orientador: Prof. Dr. Alberto Consolaro

Bauru 


\section{CASTRO, CARLOS HENRIQUE BETTONI CRUZ DE}

C279c Caracterização clínica, radiográfica e molecular em pacientes com Síndrome de Van der Woude / Carlos Henrique Bettoni Cruz de Castro- Bauru, 2006.

89 f.: $30 \mathrm{~cm}$.

Bauru.

Dissertação (Mestrado) Faculdade de Odontologia de

Orientador: Prof. Dr. Alberto Consolaro

Data de aprovação pelo Comitê de Ética em Pesquisa do Hospital de Reabilitações de Anomalias Craniofaciais-USP: 31 de outubro de 2005. Processo $n^{\circ}$ 290/2005.

A cópia do parecer de aprovação encontra-se no capítulo "Anexo".

Autorizo, exclusivamente para fins acadêmicos e científicos, a reprodução total ou parcial desta dissertação, por processos fotocopiadores e outros meios eletrônicos.

\section{ASSINATURA}

Bauru, de de 2006. 



\section{Carlos HerriqueBettori Onz deCastro}

12 de setembro de 1971

Belo Horizonte - MG

Jésus de Castro

Maria do Pilar Bettoni Cruz de

Castro

$1991-1994$

$2003-2006$

$2005-2006$

2006 até a presente data
Nascimento

Filiação

Curso de Odontologia - Faculdade de Odontologia, Universidade Federal de Minas Gerais (UFMG)

Residência em Cirurgia Bucal e Ortognática Hospital de Reabilitação de Anomalias Craniofaciais - Universidade de São Paulo.

Programa de Pós-graduação de Mestrado em Odontologia, Área de Concentração em Patologia Bucal, na Faculdade de Odontologia de Bauru Universidade de São Paulo.

Professor da Faculdade de Odontologia da FEAD. 


\section{"Se eu vi mais longe, foi por estar de pé sobre os ombros de gigantes"}

I saac Newton 1642-1727 


\section{DEDICATÓRIA}

Dedico este trabalho principalmente à minha esposa Daniella e à minha filha Gisele. Sei que fui um marido e um pai ausente nesse período. Perdi muitos momentos e acontecimentos importantes e únicos nesses anos. Só nós sabemos o que passamos separados para podermos estar aqui. Porém, quando a saudade aparecia e as forças se exauriam, sempre tinha vocês me apoiando e tornando esta jornada mais amena. Espero, agora, poder retribuir todo o tempo perdido. Esta conquista é mais suas que minha. Amo muito vocês.

Dedico também aos meus queridos e amados pais, Jésus e Pilar (in memorian) por todos os ensinamentos e pelos exemplos de vida. Por terem feito os nossos sonhos, seus sonhos. Agradeço a vocês por ter tido uma família bem estruturada e ter sempre aprendido a importância de ser correto e respeitoso com todas as pessoas. Se não tivesse tido vocês como exemplos, provavelmente não teria conseguido. Admiro e amo vocês. 


\section{AGRADECIMENTOS ESPECIAIS}

A Deus que em todos os momentos difíceis e que pareciam intermináveis, sempre esteve comigo e minha família, dando-nos forças e sabedoria e nos mostrando que tudo era passageiro. Pela infinita bondade, concedeu-me a dádiva maravilhosa da Vida e me presenteou com uma família exemplar, com uma esposa maravilhosa e companheira, amigos verdadeiros, e o maior presente de todos, o nascimento, a perfeição e o sonho realizado de ser pai da Gisele.

Ao meu querido orientador e amigo, Professor Dr. Alberto Consolaro, que me recebeu de braços abertos e proporcionou um enriquecimento ímpar na minha formação, estimulando e abrindo as minhas portas para a docência. Tenho no senhor um exemplo de profissional correto, incansável, metódico e dedicado, onde sempre buscarei inspiração. Juntamente com sua esposa Maria Fernanda Martins-Ortiz Consolaro me deram o bom convívio e o privilégio de poder estar em suas companhias e do aconchego de sua casa. Serei sempre grato a vocês por tudo que fizeram por mim e pela minha família.

Ao meu co-orientador, meu grande amigo e mestre Professor Dr. Antonio Richieri-Costa, meu mais sincero e eterno agradecimento por ter ti conhecido e ter podido fazer parte da sua equipe. Agradeço pelos ensinamentos e pela constante alegria da sua presença. Aprendi com seus ensinamentos, sua humildade e seu jeito espontâneo. Eu te admiro imensamente e te agradeço pelo privilégio de ter tido como chefe do setor onde desenvolvi esse trabalho. 


\section{AGRADECIMENTOS}

À minha querida irmã Cristiane, meus queridos sobrinhos Lucas e Marina e ao meu querido irmão Fábio pelos bons momentos que passamos juntos, pela força e pela amizade em todos os momentos difíceis. Agradeço por todos os momentos que eu voltava para Belo Horizonte e podia ter a convivência familiar de vocês. Finalmente, conseguimos.

Aos meus sogros, Mauro Reis e Lúcia Bernadete. Nunca conseguirei e poderei compensá-los pelo que fizeram por mim, minha esposa e minha filha. Sempre serei grato a vocês. Agradeço a Deus por poder fazer parte desta família.

Aos meus grandes amigos e irmãos da vida Marcelo Rosa de Lima, Luciano Ferreira Drager e Gustavo Batista de Menezes. Pela amizade gratuita e por sempre me apoiarem e estarem ao meu lado e da minha família. Ao meu amigo e professor Davidson Rodarte Felix de Oliveira por toda a força nos momentos difíceis e os conselhos.

Aos meus cunhados Mauro, Fabrício, Raphael e Eveline por terem sido mais pai do que tios para minha filha Gisele. Obrigado pela amizade e pela ajuda.

Ao Hospital de Reabilitação de Anomalias Craniofaciais (HRAC), da Universidade de São Paulo, nas pessoas do superintendente Prof. Dr. José Alberto de Souza Freitas (o "Dr. Gastão") e da presidente da Comissão da Pós-Graduação Prof a Dra. Inge Elly Kiemle Trindade, por terem me dado a oportunidade de buscar os dados e a amostra para a confecção desta dissertação.

À Faculdade de Odontologia de Bauru, da Universidade de São Paulo, através do seu atual diretor Prof. Dr. Luis Fernando Pegoraro e à Comissão de Pós-Graduação, na pessoa do atual presidente Prof. Dr. José Carlos Pereira. 
À toda família do "Centrinho", sem exceção, por terem me acolhido e terem me adotado como um ente querido. Vocês ganharam um amigo e um admirador desta belíssima obra. Tenho orgulho de ter vivido três anos aí e ter sido parte deste trabalho. Todos sempre estarão presentes nos meus pensamentos e no meu coração. Muito obrigado, de verdade.

À toda equipe da Cirurgia Bucal e Ortognática do "Centrinho", em especial a Dra. Roberta Martinelli por ter ajudado a mim e minha família nos momentos mais difíceis e pela franca amizade com todos nós. Aos meus amigos residentes Giuliano Luchi e Cláudia Felício pela ajuda, força, amizade e pelos bons momentos que passamos. A Ednéia pela amizade e força dadas a mim e à minha família. Aos Drs. Reinaldo Mazzotini, Roberto Macoto e Renato Faco, pelos ensinamentos.

À equipe da Genética do HRAC, nas pessoas da Prof ${ }^{a}$. Dra. Lucilene Arilho Ribeiro, D. Cida, Giselda Santiago e Melissa Antonelli, pela amizade, pelos constantes e bons momentos vividos. Sentirei saudades.

Aos professores-doutores da Disciplina de Patologia Bucal, Luís Antônio de Assis Taveira, Denise Tostes de Oliveira, Vanessa Soares Lara, por todos os ensinamentos passados, pelos momentos prazerosos e pela amizade sincera. Meu muito obrigado.

Aos funcionários da Disciplina de Patologia Bucal, Maria Cristina Carrara Felipe, Fátima Aparecida Silveira, Sr. Valdir João Afonso e Luís Fernando Bernardi pelo ambiente prazeroso, pela amizade e por me acolherem como um membro da família. Muito obrigado.

Ao Richerland, Oziel e Rodrigo pela presteza e pela ajuda em todos os momentos.

Aos amigos da pós-graduação da Patologia Bucal: Camila Rodini, Bethânia e Tiago Pinheiro, Erick Pedreira, Leda Francischone, Renata Falchete, Renata Consolaro, Patrícia Freitas, Milton Santamaria, Gisele Dalben, Rosário Zedebski, Suzana Figliolia, 
Marta Miyazawa, Roberta Esberard, Michele Pereira, Karen Balassiano e Melaine Lawall. Por todos os bons momentos e pela amizade.

Às amigas do Mestrado da Patologia Bucal, FOB-USP, Ana Carolina Cuzzol, Érika Sinara, Erika Pereira, Janaína Ghizoni e Simone Faustino, pela amizade, pela ajuda, pelo convívio harmonioso, por todos os momentos vividos. Vou levar comigo um pouco de cada uma de vocês. Muito obrigado.

À Sra. Fátima Cristina de Souza, do setor de Marcação de Consultas do HRAC, pela presteza e disposição no agendamento dos pacientes deste trabalho. Muito obrigado.

Ao bioestatístico do HRAC, Marcel Frederico de Lima Taga, que me ajudou nos cálculos e na análise dos dados estatísticos.

Aos funcionários da Biblioteca e Documentação da FOB-USP e da Unidade de Ensino e Pesquisa do HRAC USP, pela ajuda constante em todos os momentos.

A todos os colegas da Pós-Graduação de todas as disciplinas e aos graduandos de Odontologia da FOB-USP, em especial à Turma XLIII, pelo respeito, amizade e cordialidade.

Ao diretor-geral da FEAD Prof. Dr. José Roberto Franco Tavares Paes e ao coordenador das Áreas da Saúde e da Faculdade de Odontologia da FEAD, Prof. Dr. Rodrigo Richard da Silveira, por confiarem na minha pessoa e por terem me dado a oportunidade de lecionar e desenvolver a docência, e em especial, a todos os meus alunos desta conceituada instituição.

À CAPES, pelo auxílio pecuniário. 


\section{SUMÁRIO}

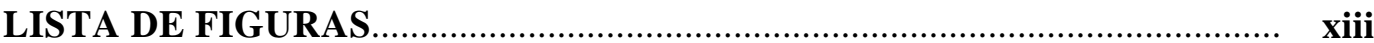

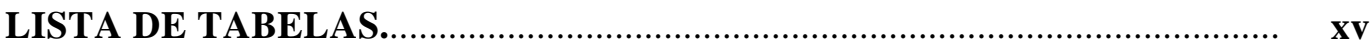

LISTA DE ABREVIATURAS, SIGLAS E SÍMBOLOS ............................... x. xvii

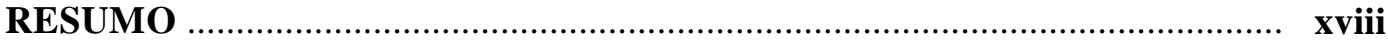

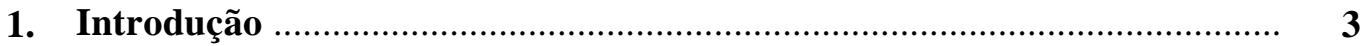

2. Revisão de Literatura .............................................................................. 11

2.1 Embriologia das fissuras faciais ................................................... 11

2.1.1 Formação dos terços médio e inferior da face .................................. 11

2.1.2 Os processos faciais ..................................................................... 12

2.1.3 A formação do palato ..................................................................... 13

2.1.4 A formação das fissuras faciais ....................................................... 15

2.2 Classificação das fissuras faciais ........................................................ 15

2.2.1 Fissura Pré-forame ou Tipo I ....................................................... 16

2.2.2 Fissura Trans-Forame ou Tipo II ................................................ 16

2.2.3 Fissura Pós-Forame ou Tipo III ........................................................ 17

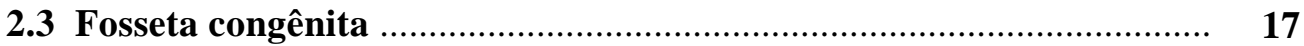

2.3.1 Características microscópicas das fossetas ....................................... $\mathbf{1 8}$

2.3.2 Classificação morfológica das fossetas .......................................... $\mathbf{1 8}$

2.3.2.1 Fossetas Bilaterais ........................................................ 19

2.3.2.2 Fosseta Unilateral …….............................................. 19

2.3.2.3 Fosseta Única ................................................................... 19

2.4 Síndrome de Van der Woude ............................................................ 19

2.4.1 Histórico da VWS .................................................................... 19

2.4.2 Etiopatogenia .................................................................... 20

2.4.2.1 O gene IRF6 ............................................................... 21

2.4.3 Características clínicas e diagnóstico diferencial ............................. 22

2.4.4 Características dentárias ........................................................... 23

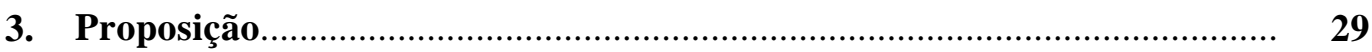




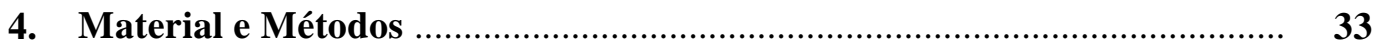

4.1 Seleção da casuística......................................................................... 33

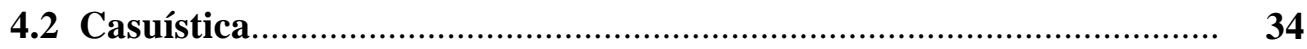

4.3 Critérios de inclusão ..................................................................... 34

4.4 Critérios de exclusão ................................................................. 34

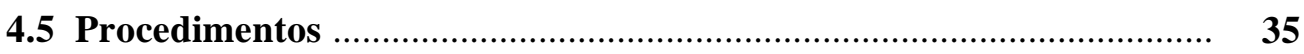

4.5.1 FASE 1- Busca e agendamento dos pacientes ............................... 35

4.5.2 FASE 2 - Coleta de dados.......................................................... 36

4.5.2.1 Avaliação clínica .............................................................. 36

4.5.2.2 Avaliação genética ............................................................... 39

4.6 Análise dos resultados..................................................................... 39

4.6.1 Análise descritiva ....................................................................... 39

4.6.2 Análise inferencial ................................................................. 40

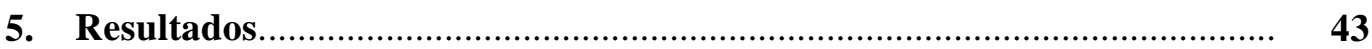

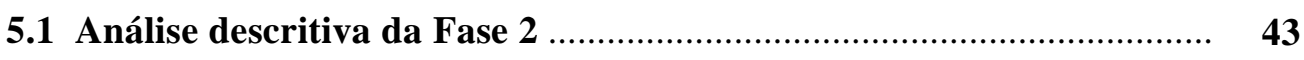

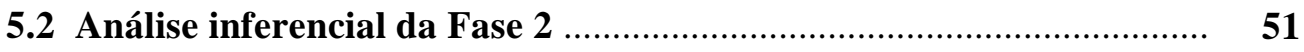

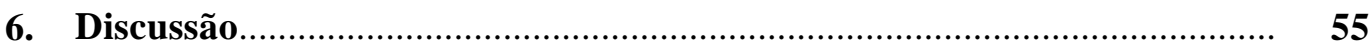

6.1 Da concepção deste trabalho ........................................................ 55

6.2 Da formação e avaliação da amostra …………………………......... 55

6.3 Considerações sobre a Síndrome de Van der Woude …….................. 56

6.4 Considerações sobre a agenesia dentária e VWS .............................. 56

6.5 Considerações sobre o tipo de fosseta e fissura .................................. 57

6.6 Considerações sobre o gene IRF6 ................................................... 59

6.7 Considerações sobre xerostomia ...................................................... 59

6.8 Associações entre fosseta, fissura, agenesia e mutação do IRF6 ......... 60

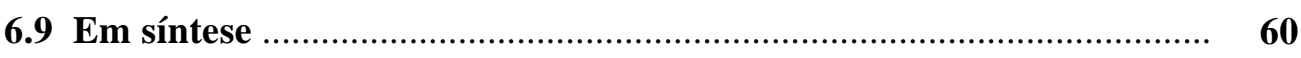

7. Conclusão

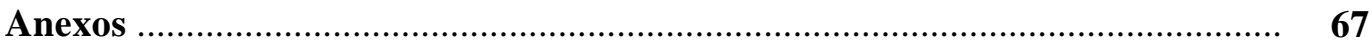

Referências Bibliográficas.................................................................. 81 


\section{LISTA DE FIGURAS}

Figura 1 Embrião de rato com 11 dias (equivale a aproximadamente 6 semanas no embrião humano). Podemos observar os processos responsáveis pela formação da face. Processo frontonasal, Processo mandibular e Processo maxilar (PM). Observe a presença de sulcos, que sofrerão nivelamento, entre os processos. PNL: processo nasal lateral; PNM: processo nasal medial. Fonte: http://www.med.unc.edu, acessado em 03/10/2006

Figura 2 Representação esquemática da fusão dos processos palatinos. (A) Inicialmente, os processos se aproximam e as células peridermais (amarelas) sobrepostas às células basais da margem epitelial medial (células brancas) emitem filópodos. (B) O primeiro contato e adesão ocorrem entre as células peridermais; proteoglicanas parecem ser importantes neste estágio. A adesão torna-se mais firme quando as células peridermais se movem para cima e para baixo (setas). (C) Células basais da margem epitelial medial de cada processo se intercalam (extensão convergente) resultando em uma única camada epitelial. (D) Camada epitelial se fragmenta e as células basais da margem epitelial medial e da periderme sofrem apoptose. (E) A camada epitelial essencialmente se degenera pela morte celular; as células mortas ativam a degradação da lâmina basal. (F) Fusão se completa sem um importante movimento das células mesenquimais, através da linha média; algumas células epiteliais nasais e bucais se movem pela linha média (setas duplas). Células rosas representam células mesenquimais (CUERVO; COVARRUBIAS ${ }^{8}, 2004$ )

Figura 3 Exemplo de Fissura Pré-Forame ou tipo I (Fonte: casuística do HRAC)

Figura 4 Exemplo de Fissura Trans-Forame ou tipo II (Fonte: casuística do HRAC) 
Figura 5 Exemplo de Fissura Pós-Forame ou tipo III (Fonte: casuística do HRAC).

Figura 6 Exemplo de fosseta congênita bilateral do lábio inferior (Fonte: casuística do HRAC) (.........................................................................

Figura 7 Esquema do gene com seus domínios e algumas mutações já

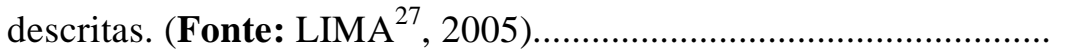

Figura 8 Radiografia panorâmica de um paciente não fissurado, examinado neste trabalho (família III - anexo 5). Observamos a ausência congênita de cinco dentes - 15, 22, 25, 35 e 45 (asteriscos vermelhos). O primeiro pré-molar superior esquerdo sofreu distalização e ocupou o lugar do segundo pré-molar ausente

Figura 9 Setor de Arquivos de Prontuários do HRAC, onde foi realizada a busca e a avaliação de todas as 111 famílias estudas por LIMA ${ }^{27}$ (2005)

Figura 10 Distribuição dos pacientes quanto ao tipo de fosseta, de acordo com a classificação de ONOFRE $^{37}$ (1987)

Figura 11 Distribuição dos pacientes quanto ao tipo de fissura, de acordo com a classificação de SPINA et al. ${ }^{52}$ (1972) 


\section{LISTA DE TABELAS}

Tabela 1 Distribuição dos indivíduos estudados quanto ao gênero e idade

Tabela 2 Distribuição dos indivíduos estudados quanto à raça

Tabela 3 Medidas-resumo das variáveis numéricas observadas

Tabela 4 Distribuição dos indivíduos estudados quanto à agenesia dentária e dentes ausentes

Tabela 5 Distribuição dos indivíduos estudados quanto o tipo de mutação encontrada

Tabela 6 Distribuição conjunta do tipo de agenesia e do tipo de mutação.

Tabela 7 Distribuição conjunta do tipo de agenesia e do tipo de fissura.

Tabela 8 Distribuição conjunta do tipo de agenesia e o tipo de fosseta.

Tabela 9 Distribuição conjunta do tipo de fissura e do tipo de mutação.

Tabela 10 Distribuição conjunta do tipo de agenesia e do tipo de mutação.

Tabela 11 Distribuição conjunta do tipo de agenesia e do tipo de fissura 
Tabela 12 Distribuição conjunta do tipo de agenesia e do tipo de

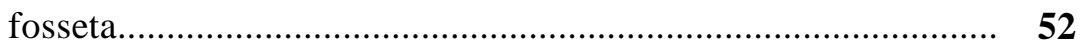




\section{LISTA DE ABREVIATURAS, SIGLAS E SÍMBOLOS}

\begin{tabular}{|c|c|}
\hline USP & Universidade de São Paulo \\
\hline FOB & Faculdade de Odontologia de Bauru \\
\hline HRAC & Hospital de Reabilitação de Anomalias Craniofaciais \\
\hline UEP & Unidade de Ensino e Pesquisa (Unidade do HRAC) \\
\hline CPD & Centro de Processamento de Dados (Unidade do HRAC) \\
\hline CEP & Comitê de Ética em Pesquisa(Unidade do HRAC) \\
\hline VWS & Síndrome de Van der Woude \\
\hline PPS & Síndrome dos Pterígeos Popliteais \\
\hline SS & Síndrome de Sjögren \\
\hline IRF6 & Gene do Fator Regulador do Interferon 6 \\
\hline DNA & Ácido Desoxiribonucléico \\
\hline PCR & Reação de Polimerase em Cadeia (Polymerase Chain Reaction) \\
\hline DICI & Distância Intercantal Interna \\
\hline DICE & Distância Intercantal Externa \\
\hline $\min$ & Minutos \\
\hline ml & Mililitros \\
\hline $\mathbf{c m}$ & Centímetros \\
\hline $\mathbf{c M}$ & Centimorgan \\
\hline KB & Kilobase \\
\hline $\mathbf{q}$ & Braço longo do cromossomo \\
\hline $\mathbf{p}$ & Braço curto do cromossomo \\
\hline
\end{tabular}




\section{RESUMO}

A Síndrome de Van der Woude (VWS) se caracteriza pela presença de fossetas congênitas no lábio inferior, associadas ou não à presença de fissura de lábio e/ou palato. Esta entidade é a forma sindrômica mais comum nos pacientes portadores de fissura labiopalatal, mesmo assim, ela é subdiagnosticada. Após o seqüenciamento do DNA, no ano de 2001, houve um aumento no interesse e no desenvolvimento de pesquisas na área de Genética Molecular Humana. Em 2002, pesquisadores identificaram no cromossomo 1, o gene IRF6 como sendo o responsável pela VWS. Neste trabalho, foram utilizados e analisados os prontuários de pacientes cadastrados e portadores da VWS do Hospital de Reabilitação de Anomalias Craniofaciais - HRAC USP, juntamente com seus familiares em primeiro-grau portadores de fissura de lábio e/ou palato, com ou sem fossetas, totalizando 22 pacientes. Foram realizados exames clínicos e radiográficos, medidas antropométricas, sialometria e heredograma de todos os pacientes. Os resultados obtidos foram confrontados com os dados resultantes do estudo genético e molecular realizado por LIMA (2005), em sua tese de Doutorado. Observamos que os achados bucais são bastante comuns no fenótipo da VWS, já que em nossa amostra tivemos $68,20 \%$ dos pacientes com alguma anomalia dentária do desenvolvimento e 45,45\% dos portadores da síndrome apresentavam pelo menos ausência de um dente. Sendo assim, o cirurgião-dentista tem importância chave tanto no diagnóstico e na avaliação bucal, quanto no tratamento dos pacientes portadores da VWS.

Descritores: Síndrome, Pesquisa em Genética, Mutação, Anodontia, Anomalias. 
I NTRODUÇÃO 


\section{1 - INTRODUÇÃO}

A Síndrome de Van der Woude (VWS) ${ }^{*}($ OMIM 119300) é uma rara desordem do desenvolvimento craniofacial de herança autossômica dominante com alta penetrância $-80 \%^{6}, 90 \%^{15}$ a $95 \%^{64}$ - e expressividade variável ${ }^{48}$. A VWS ocorre entre $0,5 \%^{57}$ a $2 \%$ e pode chegar a $6 \%^{51}$ dos pacientes com fissuras bucais ${ }^{64}$, com uma incidência na população entre $1,65 / 100.000^{47}$ a $1 / 75.000-1 / 100.000$ habitantes $^{6}$. A VWS é a forma sindrômica mais comum de fissura de lábio e/ou palato ${ }^{22,36,48}$, mas é subdiagnosticada provavelmente pela sua ampla variabilidade clínica ${ }^{36,47}$. RINTALA; RANTA $^{47}$ (1981), ao estudarem uma série com 4000 pacientes fissurados, observaram a presença de fossetas no lábio inferior em 79 indivíduos (2\%). Segundo GORLIN; COHEN; LEVIN ${ }^{15}$ (1990), a associação de fossetas com fissura de lábio e palato (FLP) está presente em 33\% dos pacientes. Este índice é também encontrado nos pacientes com fissura de palato (FP) e nos pacientes sem fissura, sendo muito rara a combinação de fissura de lábio (FL) com fossetas ${ }^{24}$. A ocorrência familial é verificada em $61 \%$ dos pacientes ${ }^{47}$.

A VWS caracteriza-se pela presença simultânea de fossetas ${ }^{* * *}$ congênitas no lábio inferior e fissura de lábio e/ou palato $(\mathrm{FL} / \mathrm{FP})^{57}$. Os pacientes com VWS mostram fossetas congênitas no lábio inferior, geralmente bilaterais, ou às vezes, pequenas elevações; FL, ou FP, por vezes isoladas,ou ainda, combinação entre estas três anomalias $^{2}$. Para se fazer o diagnóstico (isolado ou familial) desta entidade, BJÖRK et al. $^{2}$ (2003) sugerem que um indivíduo deve apresentar pelo menos um dos seguintes achados:

1. Fosseta labial isolada;

\footnotetext{
* A sigla VWS está apresentada desta forma em inglês por ser internacionalmente utilizada, facilitando a recuperação de informações pertinentes nos bancos de dados.

** OMIM 119300 (Online Mendelian Inheritance in Man) é um catálogo numerado de genes e desordens genéticas humana. Disponível no National Center for Biotecnology Information (NCBI). URL: http://www.ncbi.nlm.nih.gov/omim. Consultado em 22-ago-2006.

**** Neste trabalho utilizaremos o termo fosseta de forma generalizada para identificar as lesões labiais da VWS, e não será usado o termo fístula.
} 
2. Fosseta de lábio (as fossetas devem ser paramedianas no lábio inferior e podem aparecer clinicamente como elevações com trajeto sinuoso proveniente de glândulas presentes na mucosa do lábio) e FL e/ou FP;

3. Fosseta labial isolada e um parente em primeiro-grau com FL e FP;

4. Fissura de lábio e palato e um parente em primeiro-grau com fosseta de lábio.

A presença de retardo psicomotor não exclui a VWS, mas sugere a presença de uma microdeleção à qual tem sido observada em somente 1/310 famílias estudadas ou que ocorre de uma causa não correlacionada.

As fossetas de lábio inferior são malformações congênitas presentes em alguns pacientes com fissura labiopalatal (VWS) ou em familiares de pacientes fissurados. VAN DER WOUDE ${ }^{57}$ estimou que aproximadamente $80 \%$ dos casos de fosseta congênita ocorrem em associação com FLP. Se levarmos em consideração que a freqüência de fissuras é de aproximadamente 1:650, pode-se estimar que a freqüência de fossetas na população seja de mais ou menos 1:75.000 - 1:100.000 ${ }^{6}$. A possibilidade do portador das fossetas de lábio inferior ter um filho portador de fissura labiopalatal é sensivelmente maior do que a de um fissurado ter um filho portador da mesma condição $^{47}$. Estima-se que a probabilidade de um paciente com fosseta ter um descendente com FL e/ou FP é dez vezes maior que a probabilidade de um paciente com FL e/ou FP sem as fossetas ${ }^{6,57}$. No trabalho apresentado por RINTALA; RANTA ${ }^{47}$ (1981) a fosseta labial bilateral clássica foi encontrada em $47 \%$ dos pacientes com VWS, enquanto que diversos outros tipos mistos foram vistos em $18 \%$ e microformas em $35 \%$

As fossetas típicas são simetricamente bilaterais e suas aberturas são dispostas na borda superior do lábio inferior, se estendendo como canais revestidos por mucosa labial, cercados por glândulas mucosas em direção ao sulco labiogengival, com distância variável de $1 \mathrm{a} 25 \mathrm{~mm}$. Os canais quase sempre terminam em fundo cego. Às vezes podem ser apenas elevações cônicas e/ou superfícies abrindo sem nenhum sulco mais profundo nos seus locais típicos, presumivelmente são microformas da síndrome. Muito raramente são encontradas fossetas medianas e unilaterais ${ }^{46}$. Sua localização pode também variar na direção anteroposterior do vermelhão labial para o lado mucoso do lábio inferior ${ }^{47,48}$. 
Concomitantemente à presença de fossetas congênitas de lábio inferior, os pacientes portadores da VWS apresentam ou não fissuras bucais. A fissura de lábio e/ou palato é uma importante anomalia estrutural congênita, notável pela significante morbidade e complexa etiopatogenia ${ }^{7,49}$. A prevalência das fissuras bucofaciais varia de 1/500 a 1/2500 nascimentos dependendo das origens geográficas, étnicas e raciais, além do nível socioeconômico ${ }^{10,33,49}$. Ao examinarem os prontuários dos primeiros 1000 pacientes tratados no ano de 1946-1995, KROST; SCHUBERT $^{23}$ (2006) avaliaram as influências sazonais na prevalência das FL e/ou FP. Segundo estes autores, a FP é o tipo mais influenciado pelos fatores externos e os possíveis fatores responsáveis pela etiopatogenia das fissuras seriam: (1) deficiência de vitaminas e alterações na dieta materna; (2) intensidade de exposição à luz ultravioleta e (3) uso de fertilizantes e pesticidas na agricultura.

As fissuras labiais, primeiramente, resultam de uma falha na formação dos processos frontonasal e maxilares durante a sétima semana gestacional e um defeito no fusionamento dos processos palatinos, possivelmente ocorrendo como um defeito secundário na oitava semana de gestação ${ }^{41}$. Teorias mais recentes sugerem que a fissura de lábio não ocorre pelo fusionamento dos processos faciais (frontonasal e maxilares), mas pelo nivelamento destes, devido a uma deficiência na proliferação do ectomesênquima subjacente. Seguindo esta mesma corrente de pensamento, acredita-se que o único local onde ocorreria o fusionamento dos processos seria no palato secundário (lâminas palatinas do processo maxilar). A ausência do fusionamento provocaria a fissura de palato $^{55}$, o mesmo devendo ocorrer se houver falhas no nivelamento.

As FL, FP ou FLP podem ser sindrômicas ou não ${ }^{1}$. Existem mais de 300 síndromes identificadas onde a FL/P representa um dos sinais do espectro sindrômico ${ }^{7}$. Uma fissura é considerada sindrômica se o paciente possui mais de uma malformação envolvendo diferentes áreas do desenvolvimento. As mais importantes síndromes associadas com fissuras são: Síndrome de Van der Woude, Síndrome do Pterígeo Poplíteo (PPS*), EEC Síndrome (Ectrodactilia, Displasia Ectodérmica e fissura), Síndrome de Sticker, de Marshall, de Crouzon e Appert, entre outras, todas estas de caráter autossômico dominante. As recessivas, embora mais numerosas, são incomuns.

* A sigla PPS também será descrita em inglês pelo mesmo motivo citado anteriormente para a VWS. 
A FP e FL isoladas geralmente são multifatoriais. Entretanto, existem fissuras que são coincidentes com uma determinada síndrome e não fazem parte do traço fenotípico desta.

A fissura é considerada não sindrômica quando é isolada, sem causa identificável, ou quando decorre de um único evento iniciante, por comprometimento de um primórdio embrionário inicialmente normal, estando limitada a uma área do desenvolvimento.

As estimativas prévias sugerem que FP é associada com outras anomalias congênitas em 13 a 50\% dos casos, enquanto que a FLP é sindrômica em 2 a 13\% dos casos $^{1}$. Embora as fissuras sindrômicas compreendam somente uma minoria de todas as fissuras faciais, a identificação das síndromes é de extrema importância, usando para isto alguns recursos terapêuticos, tais como o aconselhamento genético correto e preciso, o manejo, a reabilitação e as orientações impostas ao paciente e aos seus pais.

Estudos epidemiológicos sugerem que a incidência varia de acordo com a localização geográfica e a raça, de 1.81/1000 na República Tcheca, 1.12/1000 no estado da Califórnia, nos Estados Unidos, e até 1/1000 na América Latina. Crianças negras têm uma menor incidência quando comparadas com crianças brancas ${ }^{10}$. A incidência de FL e FP é maior quando comparada à FP e o lado esquerdo é mais afetado que o direito nas fissuras unilaterais, numa proporção de 5:4 até duas vezes maior, respectivamente ${ }^{10,14}$.

O surgimento da proposta desta dissertação se deu a partir de uma curiosidade clínica. Ao examinar uma paciente com VWS tratada no ambulatório de Cirurgia Bucomaxilofacial do HRAC, observou-se a presença de ceratoconjuntivite, pele seca, xerostomia, reumatismo e artroses nas mãos e na coluna vertebral. Durante a anamnese, a mesma relatou ter tido púrpura trombocitopênica na infância e ter realizado a esplenectomia. Durante o exame bucal, observou-se xerostomia e algumas anomalias dentárias (hipoplasia de esmalte em diversos dentes e macrodontia do segundo molar inferior esquerdo). Suspeitou-se da presença da Síndrome de Sjögren (SS) e exames complementares foram realizados (Hemograma, Anti-La, Anti-Ro, teste de Schimmer e biópsia de glândula salivar menor), porém sem sucesso para confirmação diagnóstica. Finalmente, suspeitamos de uma sobreposição de síndromes (VWS e SS) ou de um aumento do fenótipo da VWS. Com estas suspeitas, vimos a necessidade de aprofundar 
o conhecimento e o entendimento da VWS. A existência de poucos trabalhos científicos, correlacionando a VWS com outras características bucais e dentárias, e a ausência de trabalhos, relacionando mutações no gene causador da Síndrome com suas possíveis alterações fenotípicas, estimularam-nos à realização deste trabalho. 
REVISÃo de LITERATURA 


\section{2 - REVISÃO DE LITERATURA}

A revisão da literatura está organizada por tópicos de interesse, onde procuramos descrever os textos e dados mais relevantes sobre o assunto. Inicialmente, os relativos à embriologia normal da face, a origem das fissuras faciais, o histórico da VWS, sua etiopatogenia e características clínicas e o estudo das fossetas congênitas. Posteriormente, os relativos à metodologia empregada, nesta dissertação.

\subsection{Embriologia das fissuras faciais}

Para entendermos como ocorre o desenvolvimento das fissuras de face, temos que compreender seu desenvolvimento normal, durante o período embrionário.

\subsubsection{Formação dos terços médio e inferior da face}

O desenvolvimento pré-natal é dividido em três fases sucessivas. Da concepção à gastrulação, entre o $13^{\circ}$ e o $18^{\circ}$ dias, tem-se o período pré-embrionário; deste período até a oitava semana aproximadamente e o início do terceiro mês, constitui-se o período embrionário; a terceira fase é o período fetal, que se estende até o parto. Após a fecundação do óvulo temos o início da primeira fase embrionária, onde uma seqüência de divisões celulares e eventos bioquímicos se iniciam. $\mathrm{O}$ óvulo dá origem à mórula $\mathrm{e}$ depois à blástula, sendo que após diversas divisões celulares teremos a formação de um disco didérmico, ou seja, formado por dois conjuntos celulares diferentes, um externo e outro interno, respectivamente o ectoderma e o endoderma. Isto ocorre aproximadamente entre o $13^{\circ}$ e o $18^{\circ}$ dia intra-uterino. Durante a terceira semana de desenvolvimento, o disco embrionário didérmico é transformado num disco tridérmico. Células da camada ectodérmica modificam-se e migram por entre o ectoderma e o endoderma, formando um bastão sólido que dará origem à notocorda, responsável pela sustentação do embrião primitivo. Assim, temos então o surgimento de um terceiro folheto embrionário, o mesoderma ${ }^{54}$.

A partir da terceira semana, inicia-se a segunda fase do período embrionário que se estende por mais quatro a seis semanas e caracteriza-se por grande parte da diferenciação das estruturas internas e externas (morfogênese). Este período é caracterizado pela formação do complexo facial que ocorrerá da quarta semana de vida intrauterina, até aproximadamente a oitava. Neste período, eventos chaves ocorrerão 
como a diferenciação do sistema nervoso central e da crista neural. Durante a formação do tubo neural antes do seu fechamento, um grupo de células se separa do neuroectoderma, onde sofrem intensa diferenciação e migram, dando origem a células da crista neural. Estas células participam da formação dos gânglios sensitivos cranianos e sofrem diferenciação para formar a maior parte do tecido conjuntivo da cabeça, estabelecendo assim o primórdio facial, são as chamadas células ectomesenquimais. A apropriada migração das células da crista neural é essencial para o desenvolvimento da face, dos tecidos de sustentação dos dentes e do próprio dente (exceto o esmalte, que é de origem ectodérmica $)^{54}$.

Todo este processo é geneticamente determinado e baseia-se em comunicações e sinalizações intercelulares entre o ectoderma e o mesênquima, e vice-versa, mediadas por moléculas como os fatores de transcrição e de crescimento específicos, além de matrizes protéicas extracelulares ${ }^{49}$.

\subsubsection{Os processos faciais}

A face se desenvolve entre o $24^{\circ}$ e o $38^{\circ}$ dia de gestação. No início da quarta semana do desenvolvimento humano, o estomódio, ou boca primitiva, está rodeado por processos distintos, a proeminência frontal, e os processos maxilar e o mandibular (figura 1). A parte anterosuperior da face primordial é uma grande proeminência, a proeminência frontal. Esta sofre espessamentos localizados a partir do seu ectoderma em posição rostral à abertura do estomódio e estimula o crescimento e a migração do mesênquima subjacente, dando origem a um braço lateral que é chamado de processo nasal lateral e a um braço medial, o processo nasal medial. Entre os dois processos nasais, encontra-se uma nova área formada por uma depressão, denominada processo frontonasal. Os processos nasais mediais dos dois lados, junto com o processo frontonasal originarão a porção média do lábio, a porção anterior da maxila e o palato primário, o qual formará a pré-maxila e os incisivos superiores. A porção caudal da face é composta pelo arco mandibular; o aspecto lateral da face é formado pelos processos maxilares bilaterais, que ajudarão na formação da face e do palato. Os processos maxilar e mandibular são originados do primeiro arco branquial e associados à migração das células ectomesenquimais oriundas da crista neural ${ }^{55}$. 


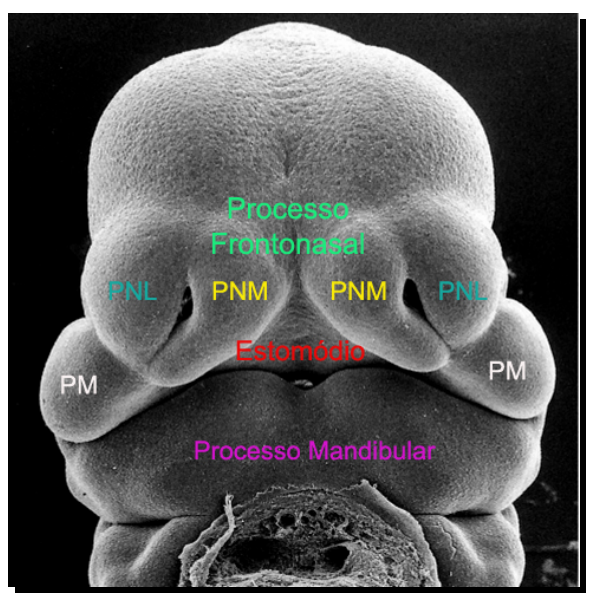

Figura 1 - Embrião de rato com 11 dias (equivale a aproximadamente 6 semanas no embrião humano). Podemos observar os processos responsáveis pela formação da face. Processo frontonasal, processo mandibular e processo maxilar (PM). Observe a presença de sulcos, que sofrerão nivelamento, entre os processos. PNL: processo nasal lateral; PNM: processo nasal medial. Fonte: http://www.med.unc.edu, acessado em 03/10/2006

Os arcos branquiais ou faríngeos formam-se na parede da faringe como resultado da proliferação da lâmina mesodérmica lateral e reforçados pela migração das células da crista neural. Os arcos são em número de seis nos seres humanos e são suportados por uma série de bastões cartilaginosos articulados, tendo em sua constituição um componente cartilaginoso, um muscular e um neuroarterial. O primeiro arco branquial dá origem à cartilagem de Meckel, aos músculos mastigatórios e ao nervo trigêmeo. A cartilagem de Meckel servirá de sustentação para que ocorra a ossificação intramembranosa da mandíbula. Estudos em ratos observaram que as células da cartilagem de Meckel sofrem apoptose através da ativação do gene p53 ${ }^{56}$ ou os condrócitos sofrem transformação por conversão fenotípica direta em fibroblasto-like; ambos os processos ocorrem e dependem da posição espacial das células na cartilagem $^{16}$. O quinto arco branquial nos seres humanos é transitório ${ }^{55}$.

Os processos maxilar e mandibular e o processo frontonasal sofrem nivelamento em seus sulcos para formar a face, através do aumento do número e da migração de células ectomesenquimais, estimuladas por interações de fatores de transcrição de origem ectodérmica e mesenquimal. Alterações neste nivelamento poderão provocar as fissuras faciais 55 .

\subsubsection{A formação do palato}

Inicialmente, existe uma única cavidade buconasal comum, limitada anteriormente pelo palato primário e ocupada principalmente pela língua em desenvolvimento. $\mathrm{O}$ palato secundário é formado entre a sétima e a oitava semanas e termina por volta da $12^{\mathrm{a}}$ semana. Embriologicamente é formado por duas porções distintas. $\mathrm{O}$ palato primário origina-se dos processos nasais mediais e frontonasal. $\mathrm{O}$ 
palato secundário é o primórdio do palato duro e mole e estende-se posteriormente à fossa incisiva. Forma-se a partir de do desenvolvimento e crescimento das células ectomesenquimais das proeminências oriundas do processo maxilar em sua porção mais posterior (processos palatinos). Para ocorrer o fechamento do palato secundário e seu nivelamento com o palato primário, a língua retira-se do espaço entre os processos palatinos e estes sofrem horizontalização. O fechamento do palato primitivo prossegue de anterior para posterior e de lateral para medial ${ }^{13}$. Na região mediana ocorrerá a fusão dos processos palatinos direito e esquerdo. As células epiteliais sofrem apoptose entre os processos palatinos, para que possa ocorrer a fusão (figura 2$)^{8,11,65}$, em um ponto específico, a partir do qual ocorrerá o nivelamento anterior e posterior.

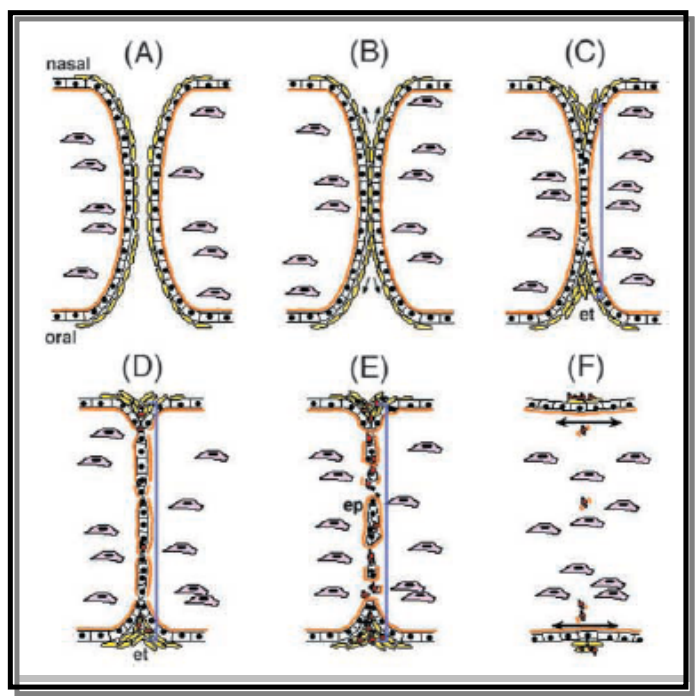

Figura 2 - Representação esquemática da fusão dos processos palatinos. (A) Inicialmente, os processos se aproximam e as células peridermais (amarelas) sobrepostas às células basais da margem epitelial medial (células brancas) emitem filópodos. (B) O primeiro contato e adesão ocorrem entre as células peridermais; proteoglicanas parecem ser importantes neste estágio. A adesão torna-se mais firme quando as células peridermais se movem para cima e para baixo (setas). (C) Células basais da margem epitelial medial de cada processo se intercalam (extensão convergente) resultando em uma única camada epitelial. (D) Camada epitelial se fragmenta e as células basais da margem epitelial medial e da periderme sofrem apoptose. (E) A camada epitelial essencialmente se degenera pela morte celular; as células mortas ativam a degradação da lâmina basal. (F) Fusão se completa sem um importante movimento das células mesenquimais, através da linha média; algumas células epiteliais nasais e bucais se movem pela linha média (setas duplas). Células rosas representam células mesenquimais (CUERVO; COVARRUBIAS $\left.^{8}, 2004\right)$ 


\subsubsection{A formação das fissuras faciais}

Qualquer fator genético ou ambiental que ocorrer durante a segunda fase embrionária, período que transcorre da $4^{\mathrm{a}}$ a $8^{\mathrm{a}}$ semana intra-uterina, poderá afetar de maneira leve ou mais grave, a formação do novo ser humano. Fatores deletérios atuando nas células em desenvolvimento podem causar malformações cranianas.

As fissuras de lábio e/ou palato são a mais comum anomalia estrutural congênita ${ }^{1}$. Tais fissuras podem resultar de: (1) falhas dos processos palatinos de se contactarem por problema de crescimento ou de um distúrbio no mecanismo de horizontalização dos processos; (2) falha dos processos palatinos em se fundirem devido a não ocorrência de apoptose das células epiteliais; (3) ruptura após ter ocorrido a fusão dos processos palatinos; (4) fusão e consolidação defeituosa do mesênquima dos processos palatinos; (5) deficiência do ectomesênquima na região facial ocasionada por falha na migração das células da crista neural ou (6) por falha do mesênquima facial em $\operatorname{proliferar}^{55,65}$.

Durante a formação da face e do palato, ocorre a ativação de vários genes, que atuando de forma harmônica e sincronizada, darão o desenvolvimento normal do complexo facial. Diversos genes desta cascata já foram identificados ${ }^{33}$. Entre os muitos genes, o MSX1 é de particular interesse, pois demonstrou que uma mutação no seu gene promove o fenótipo isolado de FL e/ou FLP, em múltiplos membros da família ${ }^{67}$. Associação do gene MSX1 com FP e do gene TGFß3 com FP, em crianças da América do Sul, sugerem que os dois loci podem interagir no aumento da susceptibilidade das

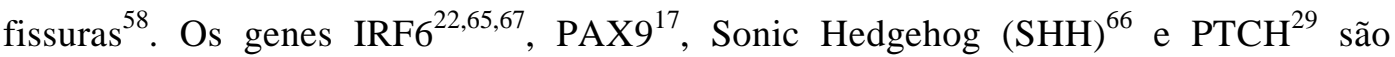
alguns dos genes que atuam na cascata de eventos para a formação da face e do palato.

\subsection{Classificação das fissuras faciais}

A classificação usada neste trabalho foi proposta por SPINA et al. ${ }^{52}$ (1972) e é usada como referência no diagnóstico e na classificação das fissuras faciais no HRAC. Esta classificação leva em consideração os critérios morfológicos da malformação, tendo como referência o forame incisivo e é dividida em três grupos: 
2.2.1 Fissura Pré-forame ou Tipo I*: completas e incompletas, uni ou bilaterais (figura $3)$.

A Fissura Pré-Forame atinge o lábio, uni ou bilateralmente, e vai desde o vermelhão, podendo chegar até o forame incisivo. Ela pode comprometer apenas o vermelhão do lábio, portanto não comprometendo a parte cutânea do lábio (incompleta), ou subir em direção ao assoalho do nariz, nos mais variados graus, até chegar ao forame incisivo, sendo então classificada como uma Fissura Completa. O comprometimento ósseo (falta de osso na fenda) pode ocorrer, embora de forma mais leve, nas fissuras incompletas, mas é normalmente maior nas fissuras completas.

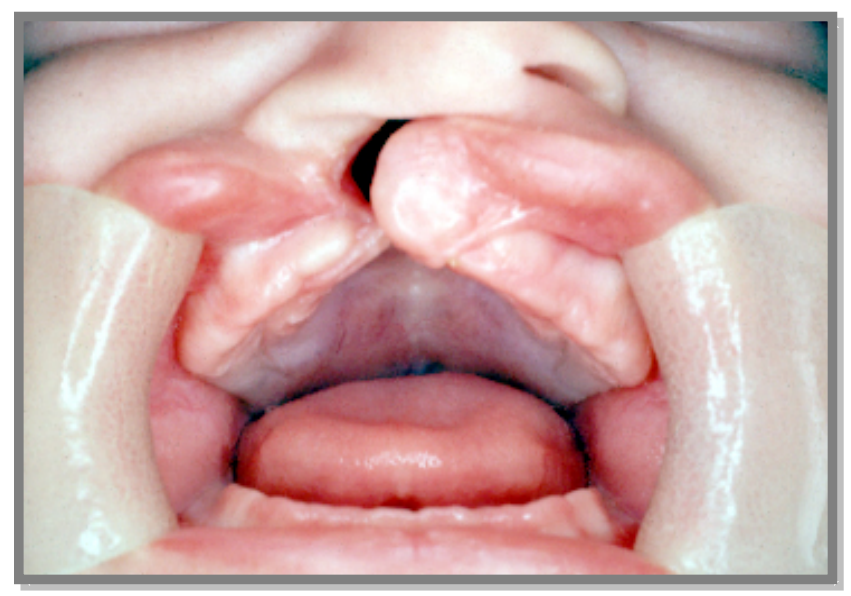

Figura 3 - Exemplo de Fissura Pré-

Forame ou tipo I (Fonte: casuística do HRAC)

2.2.2 Fissura Trans-Forame ou Tipo II ${ }^{* *}$ : uni ou bilaterais (figura 4).

A Fissura Trans-Forame atinge todo o lábio, passa através do forame incisivo, e atinge todo o palato dividindo-o em dois. Ela apresenta-se em graus variáveis de

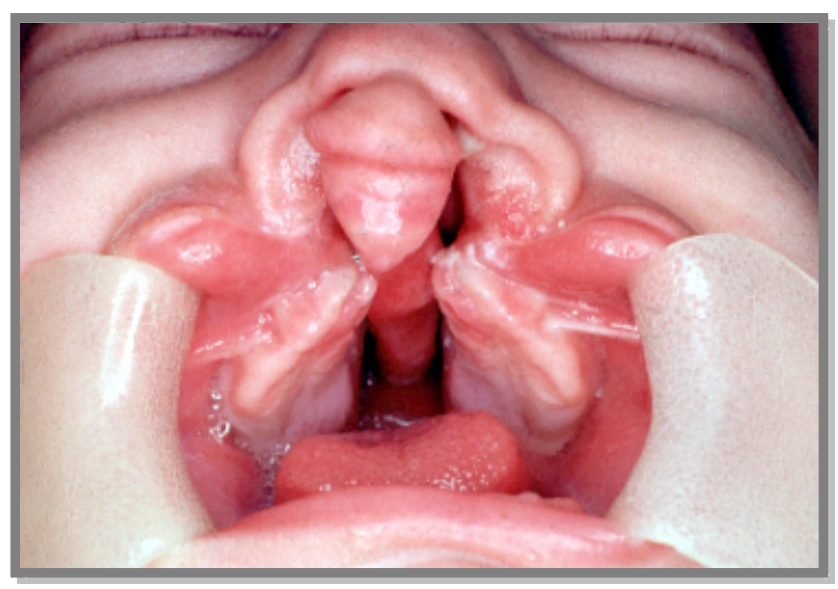

Figura 4 - Exemplo de Fissura Trans-

Forame ou tipo II (Fonte:

casuística do HRAC)

\footnotetext{
* Neste trabalho, utilizaremos a sigla FL, para identificar este tipo de fissura.

${ }^{* * *}$ Neste trabalho, utilizaremos a sigla FLP, para identificar este tipo de fissura.
} 


\subsubsection{Fissura Pós-Forame ou Tipo III ${ }^{*}$ : completas e incompletas (figura 5).}

A Fissura Pós-Forame atinge o palato, estendendo-se da úvula até o forame incisivo. Ela pode acometer apenas a úvula que pode estar apenas sulcada, ou caminhar de posterior para anterior, nos mais variados graus, até atingir o forame incisivo, e assim tornar-se-á uma Fissura Pós-Forame completa.

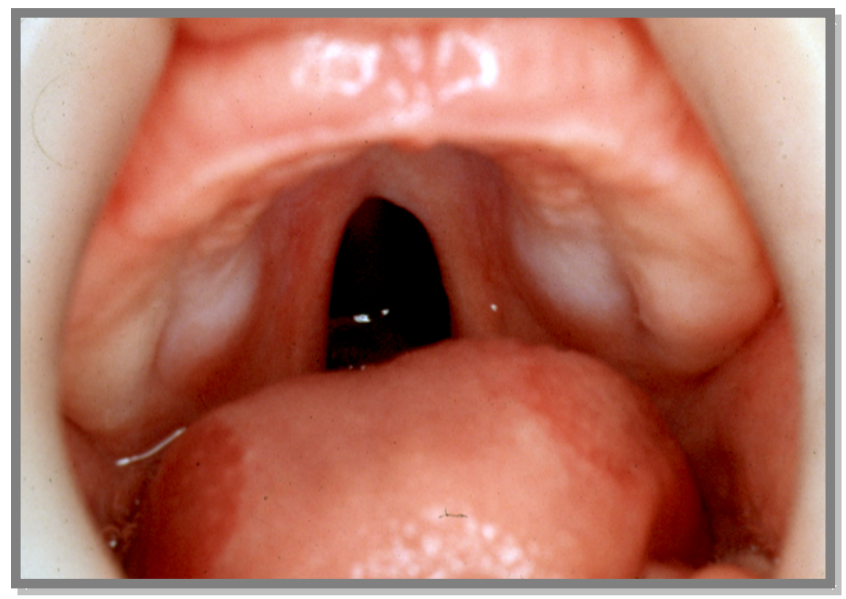

Figura 5 - Exemplo de Fissura PósForame ou tipo III (Fonte: casuística do HRAC)

\subsection{Fosseta congênita}

As fossetas do lábio inferior são malformações congênitas muito $\operatorname{raras}^{6} \mathrm{e}$ representam o achado clínico mais marcante da VWS. A frequêencia de indivíduos portadores de fossetas congênitas de lábio inferior é de 3:100.000 e a incidência da VWS, na população em geral está entre 1,65/100.000 ${ }^{47}$ a 1/75.000 - 1/100.000 habitantes ${ }^{6}$. Cerca de $90 \%$ dos pacientes afetados com a síndrome exibem fossetas congênitas no lábio inferior ${ }^{24}$. Elas são geralmente bilaterais e simétricas e se localizam na borda do vermelhão do lábio inferior, uma de cada lado da linha média. As fossetas únicas são raríssimas e representam uma expressão incompleta do traço da $\mathrm{VWS}^{6,24}$. Elas, às vezes, secretam pequena quantidade de saliva viscosa.

Segundo WARBRICK; McINTYRE; FERGUSON ${ }^{60}$ (1952), a explicação aceita para a patogênese das fossetas é que estas se originam na interrupção do desenvolvimento do sulco lateral do lábio inferior, durante a quarta semana de vida intra-uterina. Desta maneira, o sulco gradualmente torna-se obliterado, exceto na

\footnotetext{
${ }^{*}$ Neste trabalho, utilizaremos a sigla FP para identificar este tipo de fissura.
} 
extremidade cefálica. Estes sulcos tornam-se mais profundos quando o crescimento progride, estabelecendo então canais que são paulatinamente incorporados no conteúdo do lábio inferior e se persistirem, tornar-se-ão as fossetas congênitas.

\subsubsection{Características microscópicas das fossetas}

Diversos autores descreveram as características microscópicas das fossetas. As paredes da fosseta são revestidas, em toda sua extensão, por epitélio pavimentoso estratificado não queratinizado, com inúmeras papilas conjuntivas e terminam em fundo cego ${ }^{4,38,40,61}$.

As células da camada basal do epitélio são semelhantes àquelas do vermelhão do lábio e as células da camada espinhosa são volumosas, bem definidas, possuem núcleos pequenos e seu citoplasma é pouco corado. Ductos das glândulas mucosas no tecido circulante abrem dentro do lúmen das fossetas, próximo ao seu fundo ${ }^{61}$. VAN DER WOUDE $^{57}$ (1954) relatou, no seu artigo original, que na base do trato da fosseta podia ser encontrado os ácinos de diversas glândulas mucosas, com pequenos ductos comunicantes. Ao estudarem as fossetas removidas cirurgicamente, de quatro pacientes com VWS do HRAC, ao microscópico eletrônico de transmissão, ONOFRE; BROSCO; TAGA $^{40}$ (2003) avaliaram a estrutura das glândulas da parede das fossetas, para caracterizar o padrão microestrutural. As glândulas eram constituídas por ácinos mucosos típicos e possuíam células mioepiteliais ao seu redor. Em alguns lóbulos havia poucos ácinos menores e exibiam células com grânulos no seu interior. Os autores concluíram que as glândulas, apesar de se localizarem no vermelhão do lábio, mostraram características de glândula salivar labial, com predomínio mucoso.

Diversos feixes de fibras musculares estão espalhados na submucosa. Muitos destes feixes correm paralelos com as fossetas, algumas fibras correm transversalmente e obliquamente e fazem parte do músculo orbicular da boca ${ }^{61}$.

\subsubsection{Classificação morfológica das fossetas}

Neste trabalho, classificamos as fossetas de acordo com ONOFRE ${ }^{37}$ (1987), e estas foram dividida em três grupos: 
2.3.2.1. Fossetas Bilaterais: simétricas ou assimétricas, localizadas na borda do vermelhão do lábio e/ou na face interna do mesmo ou próximo à linha mucocutânea (figura 6);

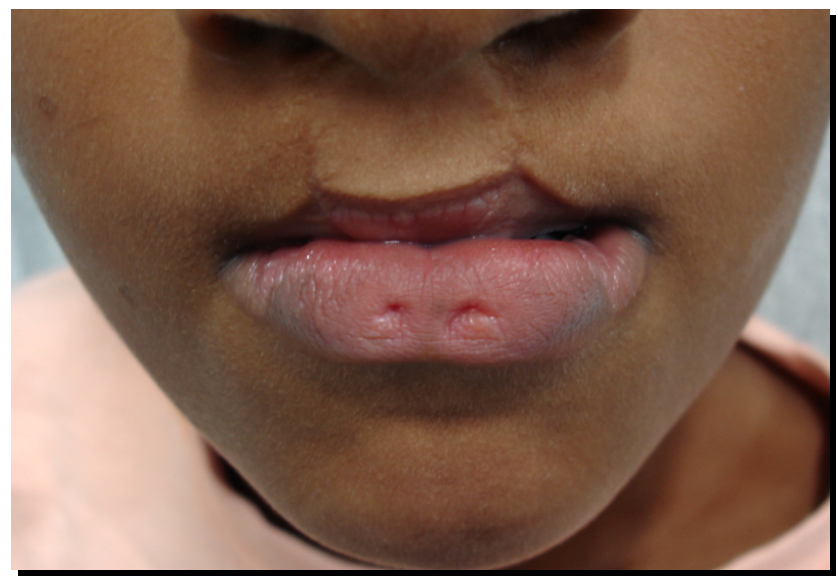

Figura 6 - Exemplo de fosseta congênita bilateral do lábio inferior (Fonte: casuística do HRAC)

2.3.2.2. Fosseta Unilateral: direita ou esquerda, localizada próxima à linha mucocutânea;

2.3.2.3. Fosseta Única: localizada na linha média.

\subsection{Síndrome de Van der Woude}

\subsubsection{Histórico da VWS}

em 1845, Demarquay foi provavelmente o primeiro a relatar uma criança com esta síndrome ${ }^{31,38,57}$. Segundo ONOFRE; TAGA ${ }^{38}$ (1994), ele relatou as fossetas em um paciente com duas depressões nas partes laterais da linha média do lábio inferior, pelas quais escoava constantemente um líquido viscoso e transparente; elas representavam os orifícios externos de duas cavidades que penetravam até $1,5 \mathrm{~cm}$ no lábio inferior e pareciam ser formadas por uma prega ou aprofundamento da mucosa.

Ao realizarem um estudo bibliométrico, WATANABE et al. ${ }^{61}$, em 1951, descreveram que diversos casos clínicos de fossetas congênitas haviam sido descritos após Demarquay. Eles relatam que Murray (1860) descreveu as fossetas como sendo “duas pequenas bolsas ou depressões” e Rose (1868) as descreveu como uma má 
formação e nomeou-as de "fístula congênita do lábio inferior". Neste trabalho bibliométrico, os autores relatam o estudo de cinco pacientes com presença de fossetas no lábio inferior; destes pacientes, três possuíam fissura de lábio e palato, uma possuía fissura mediana e um tio de uma paciente não tinha fissura. Os autores não associaram a presença da fosseta e fissura como se tratando de uma nova síndrome.

Entretanto, em 1954, a síndrome foi descrita pela primeira vez por Anne Van der

Woude $^{57}$. A autora relatou a presença da fosseta congênita no lábio inferior e sua associação com a fissura de lábio e palato. A mesma descreve o estudo de três famílias com fossetas associadas com a presença de fissura de lábio e palato, juntamente com mais duas famílias previamente descritas. Neste mesmo trabalho, Van der Woude descreve os casos como tendo um único componente genético e hereditário e cita a tríade clássica da VWS, como sendo fissura de lábio, fissura de palato e a fosseta de lábio inferior.

\subsubsection{Etiopatogenia}

Desde o artigo original de Anne Van der Woude, suspeitava-se que a síndrome tinha um caráter hereditário e era causada por alteração genética. Diversos estudos subseqüentes, para a determinação genética da mutação da VWS, foram realizados e no ano de 1987, através de estudo dos cromossomos de linfócitos de sangue periférico, BOCIAN; WALKER ${ }^{3}$ relataram uma deleção intersticial no braço longo do cromossomo 1, mais precisamente entre as bandas 32-41, em uma criança afetada com a VWS e apresentando outras anomalias adicionais. No mesmo ano, WIENKER et al. ${ }^{63}$, através do estudo do grupo sangüíneo Duffy em uma família com a síndrome, sugeriram a mutação na mesma região, sendo confirmado mais tarde por MURRAY et al. ${ }^{32}$, em 1990, através de ligação entre a VWS e marcadores específicos.

Os estudos prosseguiram até que no início deste século, KONDO et al. ${ }^{22}$, no ano de 2002, ao estudarem um par de gêmeos univitelínicos do HRAC, discordantes apenas no fenótipo da VWS (um dos gêmeos tinha fossetas e FLP, enquanto o outro não possuía nenhuma anomalia), sugeriram que ao realizar o seqüenciamento genético na região crítica 1q32-41, o único gene que diferisse entre os gêmeos seria o responsável pelas características da VWS. Uma mutação nonsense localizada no exon 4 do gene do 
Fator Regulador do Interferon 6 (IRF6) foi observada somente no gêmeo afetado e não estava presente nos pais e no irmão gêmeo. Após este achado, os autores estudaram outras 45 famílias com VWS, não correlacionadas, que tiveram identificado a mutação do gene IRF6, além de observada também mutação do IRF6 em 13 famílias afetadas com a PPS. Os autores afirmaram que a VWS é uma afecção de gene único que pode resultar em fissura tanto de palato como de lábio. Neste mesmo trabalho, os autores sugerem que a PPS e a VWS são desordens alélicas, já que possuem sobreposição fenotípica.

\subsubsection{O gene IRF6}

O gene IRF6, no seu espectro de desordens, provoca FL e/ou FP isolada e também causa VWS e PPS ${ }^{2,18,22,67}$. Localiza-se no braço longo no cromossomo 1 , a $1.6 \mathrm{cM}^{*}$ da região do 1q32 entre D1S491 e D1S205. Ele possui uma seqüência genômica com tamanho de $25 \mathrm{~KB}$ com 10 exons, dois domínios conservados, um de ligação ao DNA e um domínio de ligação a proteínas denominado SMIR (Smad Interferon Regulatory Factor binding domain), ${ }^{2,22}$ (figura 5). O gene codifica uma proteína com 467 aminoácidos. A análise seqüencial da região codificante para o gene IRF6 (exons 3 ao 9) está disponível nas bases clínicas e detecta mutações em aproximadamente $60 \%$ dos indivíduos e as mutações nos exons 3, 4, 7 e 8 são responsáveis por $82 \%$ das mutações da VWS conhecidas ${ }^{2}$.

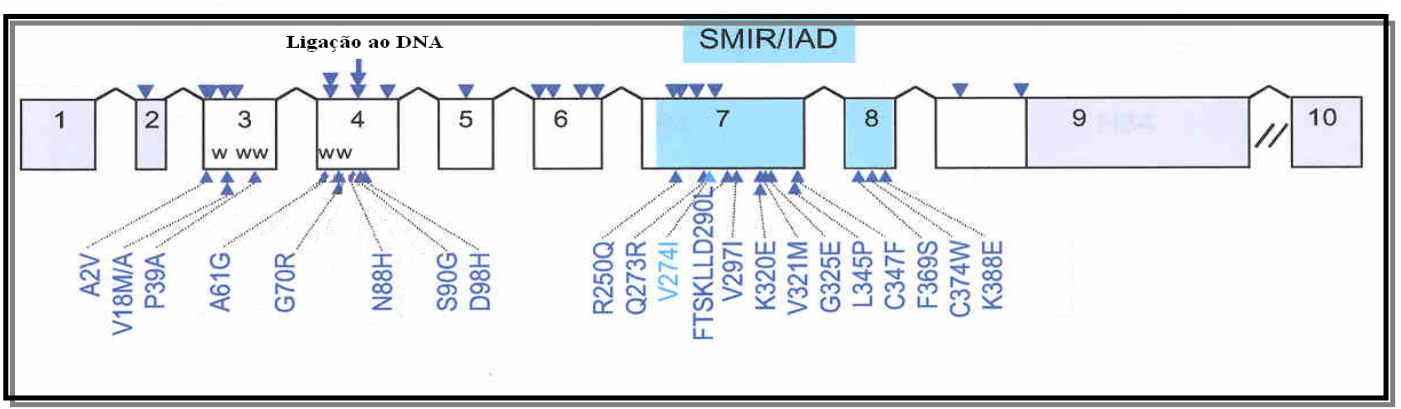

Figura 7 - Esquema do gene com seus domínios e algumas mutações já descritas (Fonte: LIMA ${ }^{27}$, 2005)

O gene IRF6 pertence à família dos Fatores Reguladores do Interferon (IRF). IRFs constituem uma família de 10 fatores de transcrição (IRF1-10) que comumente possuem um domínio modificado de ligação do DNA $\alpha$-hélice, altamente conservado

\footnotetext{
* Uma distância de 2cM corresponde a aproximadamente 2 milhões de nucleotídeos.
} 
que inclui uma repetição de triptofano ${ }^{2,22}$. Os IRFs são mediadores intracelulares que regulam a expressão dos interferons após uma infecção viral e têm um papel essencial na manutenção da homeostase celular, através da regulação do sistema imune e dos oncogenes. Recentemente, os IRFs apresentaram uma função essencial na diferenciação das células T auxiliares, tanto pela modulação das funções das células apresentadoras de antígeno quanto por alterar diretamente a transcrição de genes da citocina pelas células T. Além disto afetam a produção de óxido nítrico e o ciclo celular ${ }^{28,53}$.

Recentemente, INGRAHAM et al. ${ }^{18}$ (2006) relataram que ratos com deficiência no gene IRF6 tinham anormalidades na pele, no desenvolvimento craniofacial e nos membros. Análises histológicas e da expressão do gene indicaram que o defeito é na diferenciação e na proliferação dos queratinócitos. Assim, uma nova função para os membros da família do IRF seria o desenvolvimento epidérmico. Seguindo nesta mesma linha de pesquisa, RICHARDSON et al. ${ }^{45}$ (2006) avaliaram ratos que carreavam uma mutação homozigota do tipo missense no IRF6 e estes expressavam uma hiperproliferação da epiderme, devido a uma falha na diferenciação terminal dos queratinócitos, resultando em fusão do tecido mole. Os autores concluíram que o IRF6 desempenha papel-chave determinante na mudança da diferenciação dos queratinócitos e na sua proliferação.

ZUCCHERO et al. ${ }^{67}$ (2004) revelaram que o gene IRF6, além de conferir risco aumentado de FL e/ou P, também foi o responsável por $12 \%$ da contribuição genética para FL ou FP na cascata de eventos para a formação da face e tem um risco três vezes maior de recorrência em famílias que tem uma criança afetada.

\subsubsection{Características clínicas e diagnóstico diferencial}

Os diversos fenótipos associados com a VWS estão diretamente relacionados com a sua variável expressividade. Além das fissuras de lábio e/ou palato e da presença ou não das fossetas no lábio inferior, podemos encontrar relatos de agenesias dentárias $^{* 6,24,43,47,48,64}$; singnatia; anquilobléfaro; politelia ${ }^{42}$; sindactilia; hipoplasia do polegar $^{64}$; displasias do trato gastrointestinal (p. ex. megacólon); anomalias auriculares (p. ex. defeito no septo auricular); pescoço curto $^{3}$; possível defeito de linha média no cérebro (disgenesia do corpo caloso ${ }^{24,31}$ e colpocefalia ${ }^{24}$ ); atraso do desenvolvimento

\footnotetext{
* As ausências congênitas de dentes, neste trabalho, são genericamente identificadas como agenesias dentárias. Incluem as anodontias, as anodontias parciais (hipodontias) e oligodontias.
} 
mental $^{3}$; estrabismo divergente; hidrocefalia ${ }^{24}$; anquiloglossia ${ }^{36}$; defeitos cardíacos e doença de Hirschsprung ${ }^{9}$.

Atenção especial deve ser dada também ao diagnóstico diferencial da Síndrome do Pterígeo Poplíteal (PPS), já que está entidade, por ser alélica ao VWS, apresenta FL/P; fossetas de lábio inferior; eminências simétricas no lábio inferior; pterígeos poplíteais (pregas de tecido que se estende do calcanhar à tuberosidade isqueal); adesões filiformes entre as pálpebras com anquilobléfaro; anomalias esqueletais; anomalias digitais e nas unhas(p. ex. sindactilia) e genitais (criptorquia e escroto bífido, nos homens e hipoplasia dos grandes lábios e da uretra, nas mulheres) ${ }^{24,25,48,64}$. Outras duas condições, por apresentarem fossetas labiais, devem ser consideradas no diagnóstico diferencial. A Síndrome Oro-Facio-Digital tipo I (OFD) $)^{3,48}$ caracteriza-se por uma face atípica com hipoplasia da asa nasal; lábio superior curto com fissura mediana no lábio superior; fissura do palato mole; múltiplos frênulos bucais espessos; língua nodular e/ou lobulada; clinodactilia, sindactilia e braquidactilia dos dedos. A Síndrome de Kabuki ${ }^{2,62}$ caracteriza-se por retardo mental leve a moderado; FP; facie característica com fissuras palpebrais longas, pálpebra lateral inferior evertida e sobrancelhas arqueadas; retardo no crescimento pós-natal e anomalias esqueletais e viscerais. Recentemente, ao examinarmos um paciente do HRAC de 10 anos e apresentando características semelhantes à OFD (terço médio de face hipoplásico; lábio inferior proeminente e evertido, provavelmente tratando-se de uma microforma de fosseta labial; língua lobulada; múltiplos frênulos anormais; FP; agenesia e hipoplasia de unhas), adicionadas a agenesias dentárias, microftalmia e heterotopia neuronal periventricular, CASTRO et al. ${ }^{5}$ provavelmente descrevem outra síndrome com fosseta labial.

\subsubsection{Características dentárias}

A VWS tem entre os mais variantes fenótipos alterações no número de dentes. Segundo RANTA; RINTALA ${ }^{43}$ (1982) a alta freqüência de hipodontia, em seus estudos, demonstra que a agenesia dentária é uma característica da VWS. Diversos estudos em pacientes fissurados comprovam que, em geral, há associação entre as fissuras e as ausências dentárias ${ }^{12,19,21,50,59}$. Na população geral, a prevalência de agenesia (excluindo o terceiro molar) varia de 2 a $10 \%$, excluindo os terceiros molares ${ }^{26}$, enquanto que nos portadores de fissura, a prevalência de agenesia de prémolar varia de 18 a $27,8 \%^{50}$. As agenesias dentárias são defeitos do desenvolvimento 
muito comuns entre as crianças com FL e/ou FP, variando consideravelmente nos diferentes tipos de fissura. Ao estudarem um grupo de 47 crianças portadoras FP isolada e não sindrômica, apresentando agenesia de pelo menos um segundo pré-molar, KARSTEN; LARSON; LARSON ${ }^{21}$ (2005) correlacionaram a gravidade da extensão da fissura palatina com a agenesia deste dente. Os autores observaram que quanto mais extenso era o defeito palatino, maior a quantidade de ausência de pré-molares encontrada.

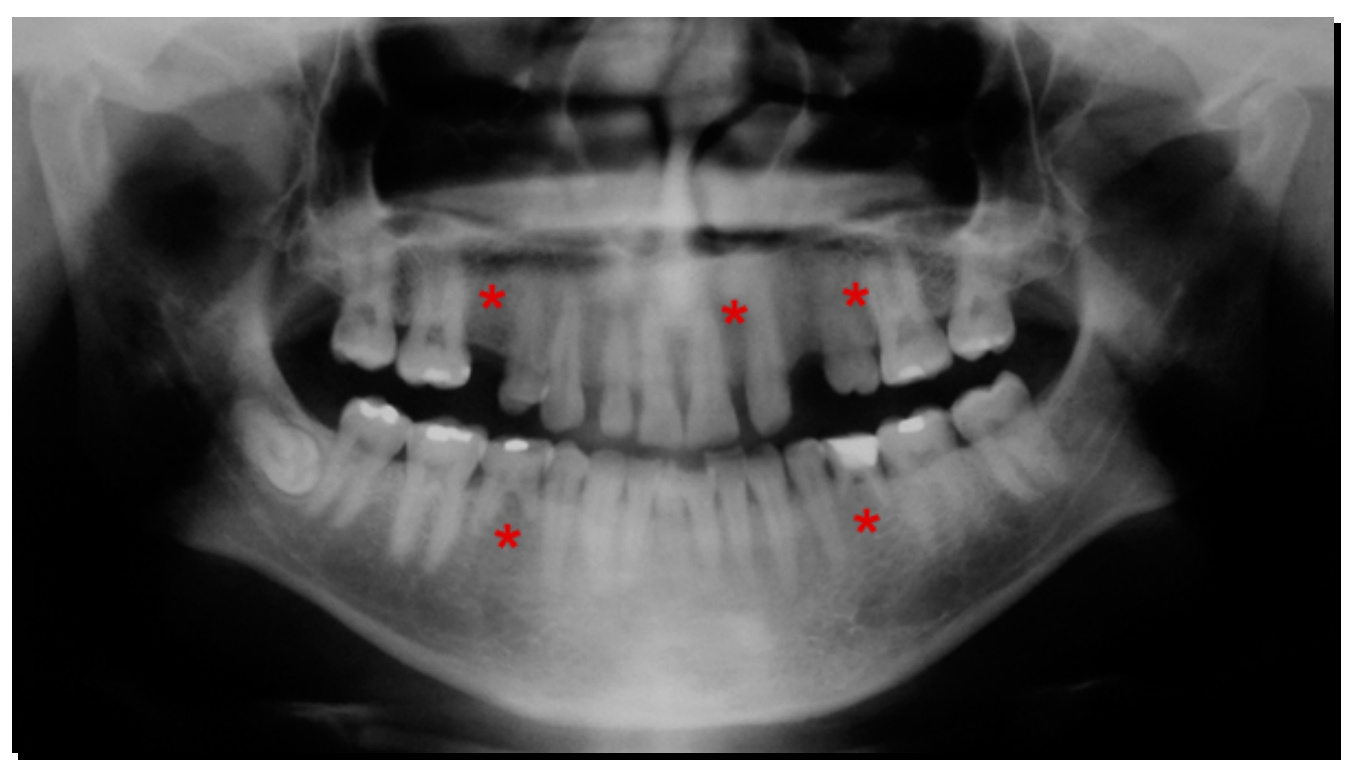

Figura 8 - Radiografia panorâmica de um paciente não fissurado, examinado neste trabalho (família III anexo 5). Observamos a ausência congênita de cinco dentes - 15, 22, 25, 35 e 45 (asteriscos vermelhos). O primeiro pré-molar superior esquerdo sofreu distalização e ocupou o lugar do segundo pré-molar ausente

No trabalho desenvolvido por RANTA; RINTALA ${ }^{43}$ (1982) foram avaliados a ocorrência de ausência congênita de dentes permanentes e o desenvolvimento assimétrico de dentes antiméricos, localizados fora da área da fissura. Os autores investigaram uma amostra de 42 crianças finlandesas com VWS (26 com FP e 16 com FL/P), variando de 7 aos 12 anos de idade, em comparação com dados de um grupo controle (não fissuradas finlandesas) e um outro grupo controle de crianças fissuradas não sindrômicas (841 crianças, idade de 7 a 12 anos). Os resultados encontrados foram os seguintes: 
1. A prevalência de agenesias dentárias foi de $65,4 \%$ dos casos de FP com VWS e $75 \%$ no grupo de FL/P com VWS e $69,1 \%$ considerando a amostra total com VWS. Nos grupos controles, a prevalência foi de $42,8 \%$;

2. Nos pacientes com VWS o número de dentes perdidos congenitamente foi de $6,3 \%$ do total de dentes examinados, enquanto nos grupos controles foram de $3,4 \%$ e quase o dobro no número de dentes perdidos na arcada superior dos portadores de VWS em comparação com os grupos controles;

3. No grupo com VWS, a prevalência de agenesias dentárias foi maior para todos os dentes. O $2^{\circ}$ pré-molar superior foi o mais freqüentemente ausente $(31 \%)$, seguido pelo $2^{\circ}$ pré-molar inferior $(23,8 \%)$ e o incisivo lateral superior $(20,3 \%)$. As porcentagens correspondentes para os grupos controles foram 20,1\%, 9,5\% e 9,6\%, respectivamente;

4. O desenvolvimento assimétrico dos pares dentários ocorreu menos discretamente nos portadores de VWS que nos grupos controles.

Em um outro estudo desses pesquisadores, pacientes com elevações cônicas e FP apresentavam ocorrência familial de fissuras e incidência de agenesias dentárias significantemente mais comuns em comparação com pacientes com FP sem elevações cônicas. Além disto, no grupo com FP a prevalência de agenesias dentárias era muito maior quando comparada com crianças finlandesas sem fissuras $(33,8 \% \text { versus } 8 \%)^{44}$.

OBEROI; VARGERVKI ${ }^{35}$ (2005) estudaram dois grupos de pacientes fissurados, um grupo com 15 crianças com a VWS e outro grupo controle com 15 crianças não sindrômicas, para avaliar e comparar a hipoplasia de maxila e a agenesia dentária. Os resultados deste estudo mostraram que os pacientes portadores da VWS apresentavam notável hipoplasia de maxila quando comparados ao grupo controle. Medidas sagitais da relação intermaxilar mostraram que o ângulo ANB e do Wits eram significantemente menores na VWS. Todos os sete pacientes portadores de FLP bilateral e FLP unilateral com VWS tinham agenesia dentária, quando comparado ao grupo controle, que apresentaram $75 \%$ e $66 \%$, respectivamente. Metade dos pacientes com VWS e FP (três pacientes) tinha ausência dentária e nenhum do grupo controle com FP tinha agenesia. O dente ausente mais freqüente foi o segundo pré-molar.

Ao observarem a ocorrência de agenesia e o desenvolvimento dentário assimétrico em um grupo de 54 crianças fissurados com seus irmãos, quando 
comparados a um grupo controle, EERENS et al. ${ }^{12}$ (2001) concluíram que os portadores de fissura e seus irmãos tinham uma freqüência de agenesia dentária e de ocorrência de assimetria no desenvolvimento dental muito maior que no grupo controle. Nesta amostra, 27,8\% dos pacientes do grupo com fissura possuíam agenesia de um dente ou de mais dentes e $50 \%$ deles possuíam um ou mais pares de dentes com desenvolvimento assimétrico. No grupo dos irmãos dos fissurados este índice chegou a $11,1 \%$ e $54 \%$, respectivamente. No grupo controle o índice foi de 3,6\% e 22,8\%. Os autores também sugeriram algum componente genético para a ocorrência de fissura e tais fenótipos.

SLAYTON et al. $^{50}$ (2003) estudaram 120 pacientes fissurados para avaliar a associação de genes candidatos (MSX1 e TGFß3) para fissura de lábio e/ou palato com a agenesia fora da área da fissura (distal aos caninos). Os autores observaram uma prevalência, nesta amostra, de 47,5\% dos pacientes com FLP e 30\% com FL com ausência de pelo menos um dente, fora da área da fissura. Além disto, agenesia fora da região fissurada foi mais provável de ocorrer em pacientes com FLP que naqueles com FL ou FP. Associação significante foi encontrada com os genes MSX1 e TGFß3 nos pacientes fissurados que possuíam hipodontia fora de sua área, sugerindo que ambos os genes têm influência na agenesia destes dentes, bem como na fissura bucofacial.

A partir do exposto e dos dados apresentados na revisão de literatura, alguns questionamentos são pertinentes. Há alguma correlação das alterações bucais nos pacientes portadores de VWS e a mutação no gene IRF6? Existe alguma relação entre a SS e a VWS ou seria um achado casual? 
Proposição 


\section{3 - PROPOSIÇÃO}

Ao examinar uma paciente portadora da VWS, com característica adicionais no seu fenótipo semelhantes à Síndrome de Sjögren (SS), como ceratoconjuntivite, pele seca, xerostomia, reumatismo e artroses nas mãos e na coluna vertebral, porém sem ter o diagnóstico confirmado da SS, vimos a necessidade de estudar e pesquisar esta família. Alguns destes fenótipos foram transmitidos para sua filha mais velha e a terceira filha era também portadora da VWS, porém sem características clínicas da SS (anexo 4 - família 6). Após este intrigante achado clínico, surgiu a idéia de estudar e aprofundar os conhecimentos da VWS. A partir dos questionamentos elaborados e com base na literatura pertinente, propusemo-nos a:

1. Verificar a relação entre os diferentes tipos de mutações encontradas nos portadores de VWS e seus diferentes fenótipos relacionados a agenesias e anomalias dentárias e alterações do sistema estomatognático;

2. Verificar quais os dentes mais freqüentemente ausentes (excluindo os terceiros molares e os ausentes na região da fissura);

3. Verificar a correlação entre diferentes tipos de fissuras e/ou fossetas de lábio inferior com as diferentes mutações encontradas no gene IRF6. 
MAteri al e Métodos 


\section{4 - MATERIAL E MÉTODOS}

O presente estudo foi realizado no Setor de Genética Clínica do Hospital de Reabilitação de Anomalias Craniofaciais (HRAC), da Universidade de São Paulo (USP - Bauru), iniciado após aprovação do Comitê de Ética em Pesquisa deste hospital, atendendo a todos os dispositivos das Resoluções 196/96 e 251/97 e aprovado sob o protocolo $\mathrm{n}^{\circ}$ 290/2005-UEP-CEP, de 31 de outubro de 2005 (Anexo 1).

\subsection{Seleção da Casuística}

A seleção da casuística foi realizada a partir do levantamento realizado por LIMA $^{27}$ (2005), em seu trabalho de doutorado, realizada com 111 famílias brasileiras não relacionadas, com pelo menos um membro portador de VWS, do HRAC, junto ao Centro de Processamento de Dados (CPD) do Hospital. Além destes, que já tinham diagnóstico prévio, foram incluídos os parentes em primeiro-grau que não se encontravam catalogados na amostra, portadores de FL e/ou P, ou com fossetas congênitas.

Para o registro manual e digital dos dados gerais dos pacientes, uma ficha clínica (anexo 4) foi utilizada, contendo os seguintes itens: identificação do paciente; endereço; gênero; idade; raça; tipo de fissura e de fosseta; presença ou não de secreção pela fosseta; tipo de secreção; dentes ausentes; anomalias dentárias presentes; alterações bucais e sua localização; alterações clínicas e radiográficas; presença de boca e olhos secos e irritação ocular; tipo de mutação; perímetro cefálico; peso e altura; sialometria em repouso; distância intercantal interna (DICI) e externa (DICE); peso e altura ao nascimento; tempo gestacional e o tipo de parto, além do heredograma, considerando três gerações, incluindo o paciente analisado.

Todos os pacientes e seus responsáveis foram convidados a participar do estudo e a assinarem o Termo de Consentimento Livre e Esclarecido (Anexo 3), após leitura da Carta de Informação ao Paciente (Anexo 2). Somente os pacientes ou responsáveis que 
assinaram esse termo, confirmando assim sua concordância e adesão ao estudo, foram incluídos na casuística.

\subsection{Casuística}

Participaram deste estudo 22 indivíduos portadores da VWS, totalizando 16 famílias na faixa etária de 5 a 48 anos completos, de ambos os gêneros (anexo 6 e 7).

\subsection{Critérios de Inclusão}

Para serem incluídos neste estudo, os participantes deveriam obedecer a alguns critérios:

- Pacientes que haviam participado da avaliação clínica e molecular realizada por LIMA $^{27}$ (2005), ou seus parentes de primeiro-grau, com presença de fissura e/ou fosseta congênita, confirmando o diagnóstico da VWS;

- Pacientes com tomadas radiográficas (Ortopantografia e/ou oclusal/periapical) realizadas no Setor de Radiologia do HRAC ou possuir no arquivo do Hospital, radiografias que pudessem ser examinadas, independente de gênero ou idade, para a avaliação de anomalias dentárias morfológicas e/ou de número. Se o paciente não tivesse radiografias ou se não fossem conclusivas para a avaliação radiográfica, estas seriam realizadas no mesmo momento do exame clínico.

\subsection{Critérios de Exclusão}

Foram estabelecidos os seguintes critérios de exclusão para os indivíduos do estudo:

- Pacientes menores de 5 anos;

- Pacientes que não tinham radiografias para diagnosticar as anomalias dentárias. 
Neste momento, quatro pacientes foram impedidos pela coordenação do setor de Radiologia do HRAC de realizar as tomadas radiográficas (dois pacientes com três anos e dois pacientes com 5 anos). Os mesmos possuíam idade inferior aos 8 anos e não poderiam ser submetidos a radiação, segundo critérios deste setor. Apesar do impedimento de pacientes menores de 8 anos na realização das tomadas radiográficas, já havíamos examinado e possuíamos as radiografias de quatro pacientes com idade de 5 a 7 anos. Estes pacientes foram incluídos na amostra.

- Paciente que não pode ou não compareceu à consulta clínica agendada, que fora realizada de janeiro a julho de 2006.

O paciente que não conseguisse realizar a sialometria devido, por exemplo, a pouca idade, não seria excluído da amostragem. Este seria usado na amostra e identificado para fins estatísticos.

\subsection{Procedimentos}

Os procedimentos realizados neste estudo foram divididos em duas fases:

- Fase 1, que consistiu na coleta dos dados e avaliação radiográfica;

- Fase 2, que foi a realização dos exames clínicos, confecção dos heredogramas, tomadas radiográficas e das demais medidas.

\subsubsection{FASE 1 - Busca e agendamento dos pacientes}

Esta etapa consistiu na busca dos prontuários, realizada no Setor de Arquivos do HRAC. Neste momento, foram examinados todos os prontuários dos pacientes avaliados por $\mathrm{LIMA}^{27}$ (2005). Ao todo, foram examinados os prontuários das 111 famílias e todos os pacientes tiveram seus números de registros encaminhados para marcação posterior de consultas, realizada pela Central de Agendamento do Hospital. 


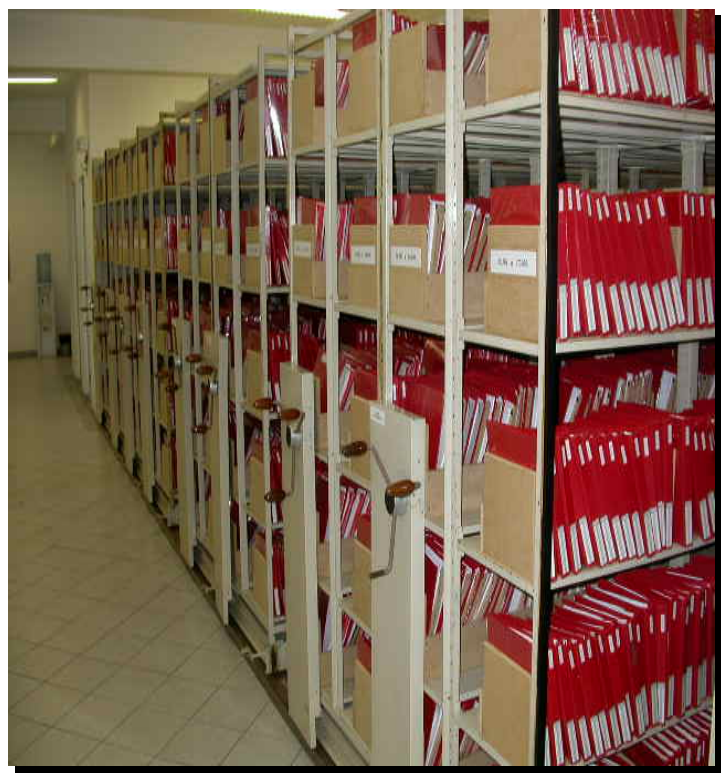

Figura 9 - Setor de Arquivos de Prontuários do HRAC, onde foi realizada a busca e a avaliação de todas as 111 famílias estudadas por LIMA $^{27}$ (2005)

\subsubsection{FASE 2 - Coleta de dados}

\subsubsection{Avaliação clínica}

Os procedimentos descritos neste item foram realizados em todos os indivíduos estudados e foram divididas em variáveis, que foram analisadas individualmente ou em associações.

\section{Variáveis do estudo}

As variáveis, neste trabalho, foram as que se seguem:

- Idade (consideradas como anos completos);

- Presença ou não de agenesia dentária e qual o dente(s) ausente(s). Neste momento foram excluídos os terceiros molares e os incisivos laterais superiores ausentes, do lado da fissura;

- Presença ou não da fosseta e o seu tipo. Os grupos foram divididos, segundo a sua ausência ou não e em relação às características morfológicas e à sua localização:

ü Ausente;

ü Bilateral paramediana (descrita neste trabalho, para facilitar a análise e a recuperação dos dados, como bilateral); 
ü Unilateral mediana direita (descrita neste trabalho como unilateral D);

ü Unilateral mediana esquerda (descrita neste trabalho como unilateral E);

ü Única mediana (descrita neste trabalho como única);

- Presença ou não da fissura e o seu tipo. As fissuras foram divididas em:

ü Ausente;

ü Lábio (FL);

ü Lábio/Palato (FLP);

ü Palato (FP);

- Presença ou não de secreção pela fosseta;

- Tipo de secreção pela fosseta:

ü Seroso;

ü Mucoso;

- Sialometria (fluxo salivar), em ml/5min;

- Raça, de acordo com critérios subjetivos do examinador em:

ü Branca;

ü Negra;

ü Parda;

- Boca e olho secos, de acordo com critérios subjetivos do paciente e/ou de seu acompanhante, a partir de uma indagação do examinador, no momento da coleta dos dados, em:

ü Não;

ü Sim;

- Tipo de mutação encontrada no exon do gene IRF6:

ü Desconhecida (quando a mutação não se encontrava em nenhum dos outros seis exons analisados do IRF6);

ü 1

ü 3

ü 4

ü 6

ü 7

ü 9 
- Tipo de parto, segundo informações colhidas do paciente e/ou acompanhante, durante a anamnese, em:

ü Normal;

ü Cesárea;

- Peso no nascimento (g);

- Altura no nascimento $(\mathrm{cm})$;

- Perímetro cefálico - PC $(\mathrm{cm})$;

- Peso (Kg), no exame clínico;

- Altura (m), no exame clínico;

- DICI - Distância intercantal Interna (mm) e

- DICE - Distância Intercantal Externa (mm).

Definidas as variáveis e as associações que iríamos estudar, o próximo passo foi a anamnese o exame clínico e radiográfico das 16 famílias avaliadas.

Anamnese: Procedimento utilizado para obter informações específicas sobre o estado geral do paciente, bem como sua condição bucal.

Sialometria em repouso: Procedimento clínico para avaliar o fluxo salivar do paciente, durante a consulta, sem estímulos prévios. Foi realizada segundo o método de NAVAZESH; CHRISTENSEN; BRIGHTMAN ${ }^{34}$ (1992). O paciente era orientado a engolir sua saliva, antes do início do procedimento, e então cuspia em um copo descartável de $80 \mathrm{ml}$, sem engolir, durante o tempo de 5 minutos. A saliva era aspirada com seringa plástica descartável, da marca $\mathrm{BD}$, de $5 \mathrm{ml}$ e então, aguardava outros 5 minutos para que a saliva se "acomodasse" no recipiente. Após isso, a mesma era medida, em ml.

Fotografia digital: Todos os pacientes foram fotografados de frente e "closeup" dos lábios e das fossetas, para melhor avaliação.

Medidas antropométricas: Exame que permitiu avaliar as mais diversas medidas cranianas e corporais. As medições foram realizadas com fita métrica, graduada de 0 a $100 \mathrm{~cm}$ e um paquímetro eletrônico digital, da marca Starrett, modelo 
727, cat. $\mathrm{n}^{\circ}$ 727-6/150, com capacidade de 6"/150mm e resolução de $.0005 \% / 0,01 \mathrm{~mm}$ (número de série 05/45749). Os pacientes foram pesados e medidos com balança analítica, marca Welmy, modelo 110, com peso máximo de $150 \mathrm{~kg}$ e altura de $2 \mathrm{~m}$.

Após estes procedimentos, os dados foram registrados na ficha clínica e depois repassados para o computador.

\subsubsection{Avaliação genética}

Todos os pacientes com VWS foram avaliados anteriormente por LIMA ${ }^{27}$ (2005), onde foram realizadas as coletas de sangue para o seqüenciamento de DNA, através do método PCR padrão. As mutações apresentadas foram utilizadas como meio de comparação com os dados clínicos coletados.

\subsection{Análise dos resultados}

Os resultados obtidos foram analisados através de análise descritiva, de algumas associações de interesse na nossa avaliação e inferencial, através do programa $\mathrm{R}$ 2.3.1 (The R Development Core Team).

\subsubsection{Análise descritiva}

\section{Variáveis numéricas}

Para as variáveis numéricas foram calculadas algumas medidas-resumo que podem ser vistas na tabela 3 . Os box plots e os gráficos da média $\pm 2 \mathrm{EP}$ (erro-padrão) podem ser vistos nos anexos 8 e 9 , respectivamente.

\section{Associações da agenesia com as demais variáveis:}

Algumas associações entre presença ou não de agenesia e os tipos de mutação, fissura e fosseta fizeram parte deste trabalho. Abaixo a indicação de cada uma das tabelas:

- tipo de mutação (tabelas 6, 9 e 10);

- tipo de fissura (tabelas 7, 9 e 11);

- tipo de fosseta (tabelas 8 e 12). 


\section{Associação entre o tipo de mutação e o tipo de fissura:}

Da mesma maneira, a associação da fissura e o tipo de mutação encontrada no paciente com VWS foi descrita na tabela 9.

\subsubsection{Análise inferencial}

Para analisar as associações acima foi utilizado o teste exato de Fisher. 
Resultados 


\section{5 - RESULTADOS}

Devido ao número de pacientes da amostra não ser suficiente para afirmar estatisticamente suposições e probabilidades, os resultados foram apresentados em tabelas e gráficos, de forma objetiva, para melhor compreensão e serão discutidos separadamente.

\subsection{Análise descritiva da Fase 2}

Foram avaliadas 16 famílias das 111 examinadas por $\operatorname{LIMA}^{27}$ (2005), totalizando 22 pa cientes portadores da VWS. Deste total, 13 eram do gênero feminino $(59,09 \%)$ e tinham idade entre 5 e 48 anos (tabela 1$)$. A média de idade da amostra foi de 17,18 anos.

TABELA 1 - Distribuição dos indivíduos estudados quanto ao gênero e idade

\begin{tabular}{cccccccc}
\hline \multirow{2}{*}{ GRUPO } & \multicolumn{2}{c}{ GÊNERO } & \multicolumn{5}{c}{ IDADE (anos) } \\
\cline { 2 - 7 } & Masculino & Feminino & Média & Mediana & $\begin{array}{c}\text { Desvio } \\
\text { Padrão }\end{array}$ & Mínimo & Máximo \\
\hline VWS & 9 & 13 & 17,18 & 10,5 & 12,59 & 5 & 48 \\
$(22)$ & $(41,01 \%)$ & $(59,09 \%)$ & & & & & \\
\hline
\end{tabular}

A distribuição dos pacientes, em relação à cor da pele, foi de 14 pacientes brancos $(63,64 \%), 7$ pacientes pardos $(31,82 \%)$ e apenas uma paciente $(4,55 \%)$ negra (tabela 2).

TABELA 2 - Distribuição dos indivíduos estudados quanto à raça

\begin{tabular}{c|c|c|c}
\hline VARIÁVEIS & CATEGORIAS & FREQÜÊNCIA & $(\%)$ \\
\hline \multirow{3}{*}{ RAÇA } & Branca & 14 & 63,64 \\
& Negra & 1 & 4,55 \\
& Parda & 7 & 31,82 \\
\hline
\end{tabular}


Dos pacientes examinados, 7 informaram seu peso ao nascimento e a média foi 3026g e 9 pacientes ou seus acompanhantes disseram a altura após o parto e a média foi de $48,15 \mathrm{~cm}$. Em relação às medidas antropométricas colhidas dos 22 pacientes, o peso médio foi de $45,19 \mathrm{~kg}$; a altura de $1,44 \mathrm{~m}$; a distância intercantal interna (DICI) foi de $32,72 \mathrm{~mm}$ e a distância intercantal externa (DICE) de $84,58 \mathrm{~mm}$.

Ao examinarmos a média de sialometria colhida, obtivemos $1,88 \mathrm{ml}$ de saliva em 5 minutos. Algumas perguntas foram dirigidas ao paciente ou ao seu acompanhante para avaliar xerostomia e olho seco. Dos 22 pacientes da amostra, 5 (22,73\%) disseram que tinham boca seca e três $(13,64 \%)$ relataram que possuíam olho seco. Se cruzarmos estes dados, percebemos que apenas dois pacientes possuíam boca e olhos secos, simultaneamente. Quando analisamos a sialometria, dos 5 pacientes que relataram ter boca seca, quatro possuíam índice menor que $0,8 \mathrm{ml} / 5 \mathrm{~min}$ e apenas um tinha sialometria de $3,2 \mathrm{ml} / 5 \mathrm{~min}$ (anexo 6).

TABELA 3 - Medidas-resumo das variáveis numéricas observadas

\begin{tabular}{c|c|c|c|c|c|c|c}
\hline VARIÁVEIS & N & $\begin{array}{c}\text { N } \\
\text { MISSING }\end{array}$ & MÉDIA & $\begin{array}{l}\text { DESVIO- } \\
\text { PADRÃO }\end{array}$ & MÍNIMO & MEDIANA & MÁXIMO \\
\hline SIALOMETRIA (ml/5min) & 22 & 0 & 1,88 & 0,94 & 0 & 1,95 & 3,20 \\
PESO NASCIMENTO (g) & 15 & 7 & 3026 & 454 & 2400 & 2970 & 3950 \\
ALTURA NASCIMENTO (cm) & 13 & 9 & 48,15 & 1,20 & 47 & 48,00 & 51,00 \\
PERÍMETRO CEFÁLICO (cm) & 22 & 0 & 54,75 & 2,68 & 52 & 54,25 & 61,00 \\
PESO (kg) & 22 & 0 & 45,19 & 26,14 & 17,5 & 37,15 & 107,00 \\
ALTURA (m) & 22 & 0 & 1,44 & 0,19 & 1,12 & 1,46 & 1,72 \\
DICI (mm) & 22 & 0 & 32,72 & 3,54 & 27,4 & 32,22 & 42,24 \\
DICE (mm) & 22 & 0 & 84,58 & 5,96 & 74,1 & 84,48 & 98,89 \\
\hline
\end{tabular}

Ao avaliarmos o tipo de parto, 13 pacientes $(59,10 \%)$ disseram que nasceram de parto normal, 7 (31,82\%) pacientes nasceram de cesárea e dois relataram não saber. Em relação ao tempo gestacional, 16 pacientes $(72,73 \%)$ disseram ter nascido a termo, quatro $(18,18 \%)$ nasceram com oito meses e um paciente nasceu com sete meses e outro não soube informar.

Durante o exame clínico, anomalias dentárias foram observadas e catalogadas na ficha clínica do paciente. Assim, quatro pacientes $(18,18 \%)$ apresentaram hipoplasia de 
esmalte (sendo três na mesma família, mãe e duas filhas - anexos 6 e 7 - família 6); três pacientes $(13,64 \%)$ possuíam microdontia; dois $(9,09 \%)$ possuíam cúspides dos molares mais baixas; um paciente $(4,55 \%)$ tinha hiperdontia dos incisivos centrais superiores, outro tinha atraso na esfoliação dentária e mais um paciente possuía atraso na odontogênese do segundo pré-molar inferior direito, um paciente tinha um segundo prémolar superior esquerdo impactado, outro possuía um quarto molar e um outro possuía um incisivo lateral inferior direito decíduo conóide. Se somarmos os pacientes que apresentaram algum tipo de anomalias teremos 15 sujeitos da amostra $(68,20 \%$ ) (anexo 7).

Ao avaliarmos a agenesia dentária dos 22 pacientes portadores de VWS, 12 pacientes não possuíam nenhuma ausência de dentes $(54,55 \%)$ e o restante $(45,45 \%)$ apresentava pelo menos ausência de um dente (tabela 4). Quatro pacientes $(18,18 \%$ ) apresentavam agenesia de pelo menos um incisivo, dois pacientes tinham agenesia de pelo menos um pré-molar, três apresentavam ausência de pelo menos um incisivo e um pré-molar e uma paciente tinha agenesia de um canino e um pré-molar. Ao todo havia dez pacientes com agenesia, totalizando 21 dentes ausentes. O dente ausente mais comum foi o segundo pré-molar (10 dentes - 47,62\%), seguido pelo incisivo lateral com oito ausências $(38,10 \%)$, dois dentes ausentes eram incisivos centrais e um era o dente canino (tabela 3). Havia sete dentes pré-molares ausentes na arcada inferior e 3 dentes na arcada superior. $O$ segundo pré-molar inferior direito foi o dente mais freqüentemente ausente e foi observado em 5 indivíduos, o incisivo lateral superior esquerdo estava ausente em quatro pacientes, seguido pelo incisivo lateral superior direito que se encontrava ausente em três pacientes (anexo 6).

Quando avaliamos o tipo de fosseta observado nos portadores da VWS, observamos que a fosseta labial mais comum foi a bilateral, presente em 11 pacientes $(50 \%)$. Quatro pacientes $(18,18 \%)$ apresentavam fosseta unilateral do lado direito, três pacientes tinham ausência de fosseta e dois pacientes $(9,09 \%)$ possuíam ou fosseta unilateral esquerda ou fosseta única (figura 10). Dos 19 pacientes observados com presença de fosseta congênita $(90,48 \%), 12(63,16 \%)$ foram submetidos à cirurgia plástica estética (queiloplastia inferior) para sua remoção (anexo 6). A secreção de saliva pela fosseta foi observada ou relatada pelo paciente ou acompanhante, quando esta tinha sido operada, em 9 pacientes $(40,91 \%)$ e foi observada a mesma quantidade de pacientes que não tinham secreção. Havia um paciente que não se lembrava se tinha ou não secreção pela fosseta, anteriormente à cirurgia de remoção da fosseta, tampouco 
sua acompanhante se recordava. Dos 9 pacientes que tinham secreção pela fosseta, todos apresentaram durante o exame clínico ou relataram durante a anamnese, secreção com aspecto seroso, semelhante à saliva.

TABELA 4 - Distribuição dos indivíduos estudados quanto à agenesia dentária e dentes ausentes

\begin{tabular}{c|c|c|c}
\hline VARIÁVEIS & CATEGORIAS & FREQÜÊNCIA & $(\%)$ \\
\hline \multirow{4}{*}{ AGENESIA } & Ausente & 12 & 54,55 \\
& Incisivo (I) & 4 & 18,18 \\
& Pré-molar (PM) & 2 & 9,09 \\
& Incisivo (I) +Pré-molar (PM) & 3 & 13,64 \\
& Canino (C) + Pré-molar (PM) & 1 & 4,55 \\
\hline \multirow{3}{*}{ DENTE AUSENTE } & Incisivo central & 2 & 9,52 \\
& Incisivo lateral & 8 & 38,10 \\
& Canino & 1 & 4,76 \\
& $2 \circ$ Pré-molar & 10 & 47,62 \\
\hline
\end{tabular}

FIGURA 10 - Distribuição dos pacientes quanto ao tipo de fosseta, de acordo com a classificação de ONOFRE $^{37}(1987)$
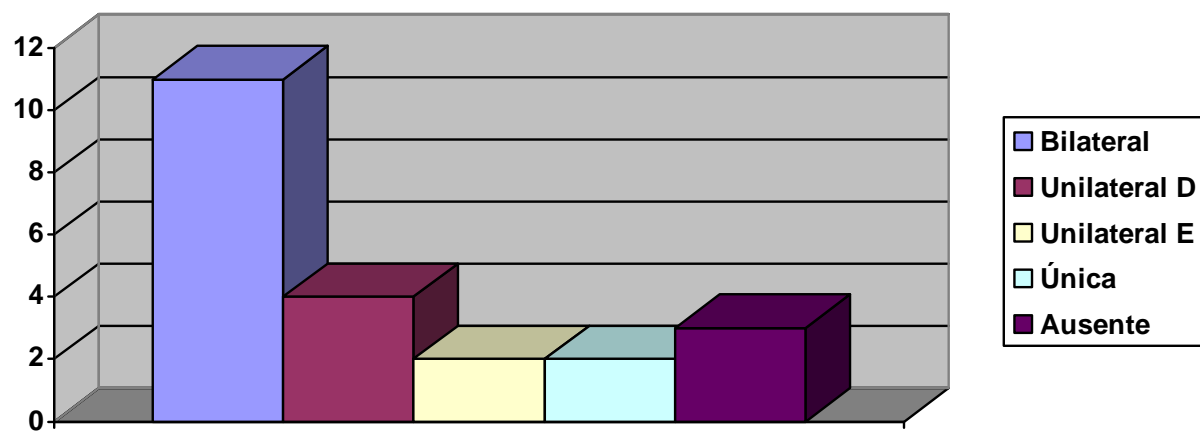

Ao examinarmos o tipo de fissura encontrada na amostra, observamos que dez pacientes $(45,45 \%)$ eram portadores de FLP, seis $(27,27 \%)$ tinham FP, quatro $(18,18 \%)$ possuíam FL e dois não apresentavam fissuras (figura 11). Dos 11 pacientes que possuíam fissura unilateral, 7 tinham fissura do lado esquerdo (63,64\%). Nesta amostra não tivemos nenhum paciente com fissura mediana. 
FIGURA 11 - Distribuição dos pacientes quanto ao tipo de fissura, de acordo com a classificação de SPINA et al. ${ }^{52}(1972)$

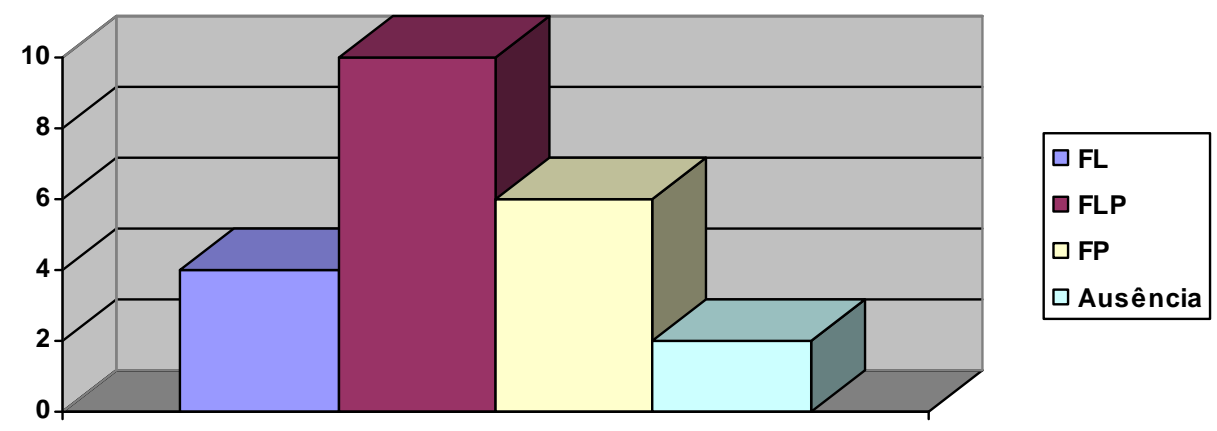

Ao analisarmos a presença ou não de fossetas congênitas com o tipo de fissura, observamos que dos 19 pacientes $(90,48 \%)$ que tinham a presença da fosseta, nove $(47,37 \%)$ eram portadores de FLP, quatro $(21,05 \%)$ tinham FP ou FL e apenas dois $(10,53 \%)$ não tinham fissura.

A distribuição do tipo de mutação, em relação aos exons do IRF6, foi de 13 pacientes $(59,09 \%)$ que tiveram a mutação identificada e de nove pacientes $(40,91 \%)$ que não tiveram descoberta a mutação gênica. Seis pacientes $(27,27 \%)$ tiveram identificados mutação no exon 4, dois pacientes apresentavam mutação nos exons 3 e 7 e um paciente tinha mutação nos exons 1,6 e 9 (tabela 4).

Na tabela 6 foi avaliado o tipo de agenesia dentária versus o tipo de mutação encontrada nos pacientes. Nesta amostra, treze pacientes apresentavam mutações em seis exons do gene IRF6 (1, 3, 4, 6, 7 e 9) e em nove portadores da VWS, a mutação permaneceu desconhecida. Para simplificar qual o dente ausente e ao mesmo tempo aumentar a amostra por grupos, estes foram distribuídos em dente com agenesia mais freqüente e também quando tinha agenesia em mais de um grupo de dentes (p. ex. incisivos, canino e pré-molares). Doze pacientes (54,55\%) não apresentavam agenesias e dez $(45,45 \%)$ tinham pelo menos agenesia de um dente. $\mathrm{O}$ exon 4 foi a mutação que maior número apresentou de pacientes com agenesia (dois), inclusive um deles tinha agenesia de um canino superior (dente 23). Todavia, o exon 6 apresentou um paciente com agenesia de quatro dentes $(12,22,35$ e 45) e em um paciente com mutação desconhecida havia ausência de cinco dentes $(15,22,25,35$ e 45) (anexo 6). 
TABELA 5 - Distribuição dos indivíduos estudados quanto o tipo de mutação encontrada

\begin{tabular}{c|c|c|c}
\hline VARIÁVEIS & CATEGORIAS & FREQÜÊNCIA & $(\%)$ \\
\hline & Desconhecida & 9 & 40,91 \\
& 1 & 1 & 4,55 \\
MUTAÇÃO & 3 & 2 & 9,09 \\
(exon do IRF6) & 4 & 6 & 27,27 \\
& 7 & 1 & 4,55 \\
& 9 & 2 & 9,09 \\
& 7 & 1 & 4,55 \\
\hline
\end{tabular}

TABELA 6 - Distribuição conjunta do tipo de agenesia e do tipo de mutação

\begin{tabular}{|c|c|c|c|c|c|c|c|c|c|c|c|c|}
\hline \multirow{2}{*}{ MUTAÇÃO } & \multicolumn{10}{|c|}{ AGENESIA } & \multirow{2}{*}{ Total } & \multirow{2}{*}{$(\%)$} \\
\hline & Ausente & $(\%)$ & I & $(\%)$ & PM & $(\%)$ & $\mathrm{I}+\mathrm{PM}$ & $(\%)$ & $\mathrm{C}+\mathrm{PM}$ & $(\%)$ & & \\
\hline Desconhecida & 3 & $(13,64)$ & 3 & $(13,64)$ & 1 & $(4,55)$ & 2 & $(9,09)$ & & & 9 & $(40,91)$ \\
\hline 1 & 1 & $(4,55)$ & & & & & & & & & 1 & $(4,55)$ \\
\hline 3 & 2 & $(9,09)$ & & & & & & & & & 2 & $(9,09)$ \\
\hline 4 & 4 & $(18,18)$ & & & 1 & $(4,55)$ & & & 1 & $(4,55)$ & 6 & $(27,27)$ \\
\hline 6 & 0 & $(0,00)$ & & & & & 1 & $(4,55)$ & & & 1 & $(4,55)$ \\
\hline 7 & 2 & $(9,09)$ & & & & & & & & & 2 & $(9,09)$ \\
\hline 9 & 0 & $(0,00)$ & 1 & $(4,55)$ & & & & & & & 1 & $(4,55)$ \\
\hline Total & 12 & $(54,55)$ & 4 & $(18,18)$ & 2 & $(9,09)$ & 3 & $(13,64)$ & 1 & $(4,55)$ & 22 & $(100,00)$ \\
\hline
\end{tabular}

*Teste exato de Fisher $\mathrm{p}=0,4983$

Na tabela 7 foi avaliado o tipo de agenesia versus o tipo de fissura encontrada. Dez pacientes apresentavam FLP $(45,45 \%)$ e seis tinham FP $(27,27 \%)$. Se levarmos em consideração a presença de fissura de palato (FLP e FP, totalizando 16 pacientes) teremos sete pacientes $(31,82 \%)$ com agenesia. Nesta amostra, o incisivo lateral foi o dente mais ausente (esta característica fenotípica esteve presente em sete pacientes).

$\mathrm{Na}$ tabela 8 foi avaliado o tipo de fosseta versus agenesia dentária. A fosseta labial bilateral foi a mais comum e este fenótipo apresentava 6 pacientes com ausência de agenesia e 5 com agenesia dentária, porém, dos 21 dentes ausentes encontrados nesta amostra, 14 dentes $(66,67 \%)$ estavam ausentes em pacientes que tinham fosseta 
bilateral. Todos os dois pacientes com fosseta única tiveram, coincidentemente, agenesia do incisivo central superior esquerdo (anexo 6).

TABELA 7 - Distribuição conjunta do tipo de agenesia e do tipo de fissura

\begin{tabular}{cccccccccccccc}
\hline \multirow{2}{*}{ FISSURA } & \multicolumn{10}{c}{ AGENESIA } & & Total & $(\%)$ \\
\cline { 2 - 8 } & Ausente & $(\%)$ & I & $(\%)$ & PM & $(\%)$ & I+PM & $(\%)$ & C+PM & $(\%)$ & & \\
\hline Ausente & 1 & $(4,55)$ & & & & 1 & $(4,55)$ & & 2 & $(9,09)$ \\
FL & 2 & $(9,09)$ & 1 & $(4,55)$ & 1 & $(4,55)$ & & & & & 4 & $(18,18)$ \\
FLP & 5 & $(22,73)$ & 2 & $(9,09)$ & 1 & $(4,55)$ & 1 & $(4,55)$ & 1 & $(4,55)$ & 10 & $(45,45)$ \\
FP & 4 & $(18,18)$ & 1 & $(4,55)$ & & 1 & $(4,55)$ & & & 6 & $(27,27)$ \\
\hline Total & 12 & $(54,55)$ & 4 & $(18,18)$ & 2 & $(9,09)$ & 3 & $(13,64)$ & 1 & $(4,55)$ & 22 & $(100,00)$ \\
\hline
\end{tabular}

*Teste exato de Fisher $\mathrm{p}=0,9815$

Na tabela 9 observou o tipo de mutação versus o tipo de fissura. Nesta amostra obtivemos 13 pacientes com fissura que tiveram identificado o exon mutado. As FL e FLP foram encontradas em 10 pacientes $(45,45 \%)$ da amostra total, com mutação conhecida. Destes portadores de FL e FLP, cinco pacientes (50\%) tiveram a mutação no exon 4. Apenas dois pacientes com FP tiveram seus exons identificados, um tinha mutação no exon 1 e o outro no exon 6. Nove foi o total de pacientes que não tiveram identificados as sondas utilizadas para determinar o exon que sofreu mutação (exons 1, 3, 4, 6, 7 ou 9). Destes, oito pacientes $(36,36 \%)$ apresentaram fissura de palato (FLP ou FP) e o outro indivíduo não tinha fissura. Nenhum paciente desta amostra teve FL e mutação desconhecida.

Na tabela 10, os pacientes foram divididos como portadores de agenesia dentária ou não e tiveram sua associação com o tipo de mutação encontrada. Desta maneira, o grupo com agenesia com maior número de pacientes presentes ( 6 pessoas - 27,27\%) não tiveram detectada a mutação. Estes 6 pacientes foram responsáveis pela ausência de 13 dentes $(61,90 \%)$, do total de 21 dentes ausentes (anexo 6). 
TABELA 8 - Distribuição conjunta do tipo de agenesia e o tipo de fosseta

\begin{tabular}{|c|c|c|c|c|c|c|c|c|c|c|c|c|}
\hline \multirow{2}{*}{ FOSSETA } & \multicolumn{10}{|c|}{ AGENESIA } & \multirow{2}{*}{ Total } & \multirow{2}{*}{$(\%)$} \\
\hline & Ausente & $(\%)$ & I & $(\%)$ & PM & $(\%)$ & $\mathrm{I}+\mathrm{PM}$ & $(\%)$ & $\mathrm{C}+\mathrm{PM}$ & $(\%)$ & & \\
\hline Ausente & 3 & $(13,64)$ & & & & & & & & & 3 & $(13,64)$ \\
\hline Bilateral & 6 & $(27,27)$ & 1 & $(4,55)$ & 1 & $(4,55)$ & 3 & $(13,64)$ & & & 11 & $(50,00)$ \\
\hline Unilateral D & 2 & $(9,09)$ & & & 1 & $(4,55)$ & & & 1 & $(4,55)$ & 4 & $(18,18)$ \\
\hline Unilateral E & 1 & $(4,55)$ & 1 & $(4,55)$ & & & & & & & 2 & $(9,09)$ \\
\hline Única & 0 & $(0,00)$ & 2 & $(9,09)$ & & & & & & & 2 & $(9,09)$ \\
\hline Total & 12 & $(54,55)$ & 4 & $(18,18)$ & 2 & $(9,09)$ & 3 & $(13,64)$ & 1 & $(4,55)$ & 22 & $(100,00)$ \\
\hline
\end{tabular}

*Teste exato de Fisher $\mathrm{p}=0,3253$

TABELA 9 - Distribuição conjunta do tipo de fissura e do tipo de mutação

\begin{tabular}{|c|c|c|c|c|c|c|c|c|c|}
\hline \multirow{2}{*}{ MUTAÇÃO } & \multicolumn{7}{|c|}{ FISSURA } & \multirow{2}{*}{ Total } & \multirow{2}{*}{ (\%) } \\
\hline & Ausente & $(\%)$ & FL & $(\%)$ & FLP & $(\%)$ & $\mathrm{FP} \quad(\%)$ & & \\
\hline Desconhecida & 1 & $(4,55)$ & & & 4 & $(18,18)$ & $4(18,18)$ & 9 & $(40,91)$ \\
\hline 1 & & & & & & & $1 \quad(4,55)$ & 1 & $(4,55)$ \\
\hline 3 & & & & & 2 & $(9,09)$ & & 2 & $(9,09)$ \\
\hline 4 & 1 & $(4,55)$ & 3 & $(13,64)$ & 2 & $(9,09)$ & & 6 & $(27,27)$ \\
\hline 6 & & & & & & & $1 \quad(4,55)$ & 1 & $(4,55)$ \\
\hline 7 & & & & & 2 & $(9,09)$ & & 2 & $(9,09)$ \\
\hline 9 & & & 1 & $(4,55)$ & & & & 1 & $(4,55)$ \\
\hline Total & 2 & $(9,09)$ & 4 & $(18,18)$ & 10 & $(45,45)$ & $6(27,27)$ & 22 & $(100,00)$ \\
\hline
\end{tabular}

*Teste exato de Fisher $\mathrm{p}=0,0912$

Da mesma forma, na tabela 11 e na 12, levou-se em consideração apenas à presença ou não da agenesia, em associação com o tipo de fissura e o tipo de fosseta, respectivamente. O fenótipo de FLP apresentou igualitariamente 5 pacientes com presença e ausência de agenesia. Pacientes com FLP foram responsáveis pela ausência de 9 dentes $(42,86 \%)$, no total de 21. Se levarmos em consideração, pacientes portador de FP (FLP e FP) este número sobe para 14 dentes $(66,67 \%)$. O paciente que não apresentava fissura foi o que mais tinha ausência dentária (agenesia de 5 dentes), ele apresentava ausência de todos os segundos pré-molares e um incisivo lateral superior esquerdo. Quando comparamos o tipo de fosseta, a fosseta bilateral tinha um número de 
6 pacientes sem ausência de dentes e de 5 pacientes com agenesia dentária. Os pacientes com fosseta bilateral que tinham agenesia eram responsáveis por 14 dentes ausentes $(66,67 \%)$.

TABELA 10 - Distribuição conjunta do tipo de agenesia e do tipo de mutação

\begin{tabular}{ccccccc}
\hline \multirow{2}{*}{ MUTAÇÃO } & \multicolumn{5}{c}{ AGENESIA } & \\
\cline { 2 - 5 } & Ausente & $(\%)$ & Presente & $(\%)$ & & \\
\hline Desconhecida & 3 & $(13,64)$ & 6 & $(27,27)$ & 9 & $(40,91)$ \\
1 & 1 & $(4,55)$ & & & 1 & $(4,55)$ \\
3 & 2 & $(9,09)$ & & & 2 & $(9,09)$ \\
4 & 4 & $(18,18)$ & 2 & $(9,09)$ & 6 & $(27,27)$ \\
6 & & & 1 & $(4,55)$ & 1 & $(4,55)$ \\
7 & 2 & $(9,09)$ & & & 2 & $(9,09)$ \\
9 & & & 1 & $(4,55)$ & 1 & $(4,55)$ \\
\hline Total & 12 & $(54,55)$ & 10 & $(45,45)$ & 22 & $(100,00)$ \\
\hline
\end{tabular}

*Teste exato de Fisher $\mathrm{p}=0,1729$

\subsection{Análise inferencial da Fase 2}

Todas as associações realizadas neste trabalho entre as diversas variáveis avaliadas (tipo de fissura, tipo de fosseta, agenesia dentária e o tipo de mutação) tiveram o tratamento estatístico realizados. O teste utilizado nos cálculos estatísticos foi o exato de Fisher. Este teste permite calcular a probabilidade de associação das características que estão em análise serem independentes e foi considerado o de escolha pelo pequeno número total da nossa amostra.

O teste de Fisher levou em consideração a hipótese se não havia associação entre as variáveis citadas acima e todos os resultados obtidos foram superiores a $p<0,05$, não sendo possível afirmar qualquer associação avaliada. 
TABELA 11 - Distribuição conjunta do tipo de agenesia e do tipo de fissura

\begin{tabular}{|c|c|c|c|c|c|c|}
\hline \multirow{2}{*}{ FISSURA } & \multicolumn{4}{|c|}{ AGENESIA } & \multirow{2}{*}{ Total } & \multirow{2}{*}{$(\%)$} \\
\hline & Ausente & $(\%)$ & Presente & $(\%)$ & & \\
\hline Ausente & 1 & $(4,55)$ & 1 & $(4,55)$ & 2 & $(9,09)$ \\
\hline FL & 2 & $(9,09)$ & 2 & $(9,09)$ & 4 & $(18,18)$ \\
\hline FLP & 5 & $(22,73)$ & 5 & $(22,73)$ & 10 & $(45,45)$ \\
\hline FP & 4 & $(18,18)$ & 2 & $(9,09)$ & 6 & $(27,27)$ \\
\hline Total & 12 & $(54,55)$ & 10 & $(45,45)$ & 22 & $(100,00)$ \\
\hline
\end{tabular}

*Teste exato de Fisher $p=0,922$

TABELA 12 - Distribuição conjunta do tipo de agenesia e do tipo de fosseta

\begin{tabular}{|c|c|c|c|c|c|c|}
\hline \multirow{2}{*}{ FOSSETA } & \multicolumn{4}{|c|}{ AGENESIA } & \multirow{2}{*}{ Total } & \multirow{2}{*}{$(\%)$} \\
\hline & Ausente & $(\%)$ & Presente & $(\%)$ & & \\
\hline Ausente & 3 & $(13,64)$ & & & 3 & $(13,64)$ \\
\hline Bilateral & 6 & $(27,27)$ & 5 & $(22,73)$ & 11 & $(50,00)$ \\
\hline Unilateral D & 2 & $(9,09)$ & 2 & $(9,09)$ & 4 & $(18,18)$ \\
\hline Unilateral E & 1 & $(4,55)$ & 1 & $(4,55)$ & 2 & $(9,09)$ \\
\hline Única & & & 2 & $(9,09)$ & 2 & $(9,09)$ \\
\hline Total & 12 & $(54,55)$ & 10 & $(45,45)$ & 22 & $(100,00)$ \\
\hline
\end{tabular}

*Teste exato de Fisher $\mathrm{p}=0,7243$ 


\section{DIsCUSSÃo}




\section{6 - DISCUSSÃO}

\subsection{Da concepção deste trabalho}

Este estudo surgiu a partir da avaliação clínica de uma paciente que apresentou características clínicas da Síndrome de Sjögren (SS) em sobreposição à VWS, posteriormente houve a extensão para sua família (duas filhas). Como a mãe apresentava xerostomia e esta foi confirmada pela sialometria $(0,8 \mathrm{ml} / 5 \mathrm{~min})$, uma biópsia de glândulas salivares menores foi realizada para observarmos microscopicamente. Os cortes microscópicos revelaram remanescentes glandulares com atrofia acinar e ductal, fibrose intersticial e infiltrado inflamatório predominantemente mononuclear linfocitário, sugestivo de SS. Apesar destes achados, o diagnóstico da SS foi descartado e possivelmente, tratava-se de um aumento do fenótipo da VWS.

Recentemente, INGRAHAM et al. ${ }^{18}$ e RICHARDSON et al. ${ }^{45}$ (2006) relataram que ratos com mutação no gene IRF6 possuíam alterações na diferenciação e na proliferação dos queratinócitos. Estes achados corroboram com nossa observação inicial, já que nossa paciente apresentava entre outras características, anomalias do desenvolvimento de origem ectodérmica (ocular, glandular, dentária e epidérmica).

Com a observação desta família, sentimos que deveríamos aprofundar no estudo da VWS, na tentativa de aumentarmos o nosso conhecimento das características clínicas. Como LIMA $^{27}$ (2005) havia realizado um grande estudo molecular com 111 famílias com VWS, no HRAC, tínhamos uma grande amostra de pacientes com a mutação gênica identificada e vimos à necessidade de avaliarmos clinicamente e do ponto de vista odontológico estes pacientes.

\subsection{Da formação e avaliação da amostra}

No trabalho de $\operatorname{LIMA}^{27}$ (2005) foram examinadas 111 famílias com VWS do HRAC. Obtivemos deste total, uma amostra de dezesseis famílias $(14,41 \%)$, totalizando 22 pacientes para avaliarmos. O baixo número de pacientes e famílias se deu possivelmente pelo pouco tempo disponível para a avaliação (janeiro até julho de 2006) e também ao alto índice de faltas e justificativas. De um total de 45 pacientes previamente agendados, 15 pacientes $(33,33 \%)$ não compareceram à consulta clínica agendada previamente e oito pacientes $(17,78 \%)$ foram retirados da amostra, por terem menos de 8 anos e assim não poderíamos realizar tomadas radiográficas. 


\subsection{Considerações sobre a Síndrome de Van der Woude}

Apesar da VWS ser a forma sindrômica mais comum em pacientes fissurados e possuir alta penetrância de até $95 \%{ }^{64}$, esta é subdiagnosticada. Possivelmente isto se deve ao fato dos pacientes portadores de fossetas labiais congênitas inferiores serem facilmente identificados e diagnosticados. Porém, segundo BJÖRK et al. ${ }^{2}$ (2003) esta pesquisa deve ser estendida aos parentes em primeiro-grau, já que estes possuindo FL e/ou FP e tendo ausência de fossetas serão considerados portadores da mutação gênica responsável pela síndrome. Do mesmo modo, pacientes fissurados com parentes em primeiro-grau com fossetas também são portadores da VWS. Desta maneira, a avaliação deve ser estendida aos pacientes fissurados com ou sem fosseta e seus parentes em primeiro-grau, provavelmente aumentando o número de pacientes com a VWS.

\subsection{Considerações sobre a agenesia dentária e VWS}

O estudo da agenesia neste trabalho foi realizado pela avaliação radiográfica de todos os 22 pacientes analisados, através de radiografias panorâmicas arquivadas ou solicitadas, do Setor de Radiologia do HRAC. Nos trabalhos sobre a VWS, a ausência dentária é uma característica e um traço constante nos pacientes portadores da VWS. Agenesia é um achado relativamente comum em pacientes fissurados e se destaca por estar acima da média dos pacientes não fissurados. Na população geral, a prevalência de agenesia (excluindo o terceiro molar) varia de 2 a $10 \%{ }^{26}$, enquanto que nos portadores de fissura, a prevalência de agenesia de pré-molar varia de 18 a $27,8 \%{ }^{50}$.

Ao analisarmos, de um modo geral, a freqüência de agenesia dentária dos portadores da VWS, nossa amostra diferiu consideravelmente dos resultados obtidos por outros autores. Encontramos 10 pacientes $(45,45 \%)$ que apresentava pelo menos ausência de um dente. Destes pacientes com agenesia, 5 (27,27\%) eram portadores de FLP, dois tinham FP e outros dois portavam FL e apenas um não possuía fissura. Quando analisamos os 12 pacientes $(54,55 \%)$ sem agenesia dentária, 5 indivíduos $(27,27 \%)$ tinham FLP, quatro $(18,18 \%)$ eram portadores de FP, dois tinham FL $(9,09 \%)$ e um paciente não era fissurado. No trabalho desenvolvido por RANTA; RINTALA ${ }^{43}$ (1982), a prevalência de agenesias dentais foi de 65,4\% dos casos de FP com VWS e $75 \%$ no grupo de FL/P com VWS e $69,1 \%$ considerando a amostra total com VWS. OBEROI; VARGERVIK ${ }^{35}$ (2005) observaram que todos os portadores de FLP bilateral e FLP unilateral com VWS de sua amostra (7 pacientes) tinham agenesia dentária. Provavelmente, no nosso estudo e no estudo de OBEROI; VARGERVIK ${ }^{35}$ (2005), as 
amostras eram muito pequenas quando comparadas as de RANTA; RINTALA ${ }^{43}$ (1982), daí a discrepância tanto para mais quanto para menos.

Em nosso estudo encontramos 21 dentes ausentes e o dente ausente mais comum foi o segundo pré-molar (10 dentes - 47,62\%), seguido pelo incisivo lateral com oito ausências $(38,10 \%)$. Havia sete dentes pré-molares ausentes na arcada inferior e 3 dentes na arcada superior. O segundo pré-molar inferior direito foi o dente mais freqüentemente ausente (5 indivíduos), o incisivo lateral superior esquerdo estava ausente em quatro pacientes, seguido pelo incisivo lateral superior direito que se encontrava ausente em três pacientes. RANTA; RINTALA ${ }^{43}$ (1982) observaram que o $2^{\circ}$ pré-molar superior foi o mais freqüentemente ausente $(31 \%)$, seguido pelo $2^{\circ}$ prémolar inferior $(23,8 \%)$ e o incisivo lateral superior $(20,3 \%)$. Apesar de diferir tanto na freqüência quanto no tipo de dentes ausentes mais comuns, nosso trabalho sugeri uma associação da síndrome com a agenesia dentária e uma maior freqüência na ausência do dente pré-molar.

\subsection{Considerações sobre o tipo de fosseta e fissura}

O tipo de fosseta e fissura analisadas se deu por exame clínico ou através de análise dos prontuários dos pacientes, quando as fossetas foram removidas cirurgicamente. Em nossa amostra obtivemos 11 pacientes $(50 \%)$ com fosseta bilateral clássica, semelhante ao estudo de RINTALA; RANTA ${ }^{47}$ (1981) que obtiveram $47 \%$ dos pacientes com fosseta bilateral clássica. Em nosso estudo tivemos 19 pacientes $(90,48 \%)$ portadores de fosseta congênita, corroborando com o estudo de LACOMBE et al. $^{24}$ (1995). Em seu estudo, os autores relataram que $90 \%$ dos pacientes afetados com a síndrome possuíam também fossetas congênitas no lábio inferior. Segundo CERVANKA; GORLIN; ANDERSON ${ }^{6}$ (1967) e RINTALA; LAHTI ${ }^{46}$ (1973), as fossetas únicas são raríssimas e representam uma expressão incompleta do traço da VWS, porém encontramos este tipo de fosseta em dois pacientes $(9,09 \%)$, mesmo número observado nos portadores de fosseta unilateral esquerda.

Quando comparamos a presença ou não da fosseta e o tipo de fissura, nossos resultados também diferem da literatura. GORLIN; COHEN; LEVIN ${ }^{15}$ (1990) relataram que a associação de fossetas com FLP ocorreu em 33\% dos pacientes, mesmo índice observado tanto para os pacientes com FP, quanto para os pacientes sem fissura. Nossa amostra observou 9 pacientes $(40,91 \%)$ com FLP associada à fosseta, 5 indivíduos 
$(22,73 \%)$ com FP e fossetas, quatro $(18,18 \%)$ com FL associado à presença da fosseta $\mathrm{e}$ apenas dois pacientes $(9,09 \%)$ com fosseta congênita, porém sem a presença de fissura.

As fissuras foram avaliadas e classificadas seguindo o critério de SPINA et al. ${ }^{52}$ (1972), mesmo critério utilizado no HRAC. No nosso trabalho, consideramos a seguinte divisão: grupo I (FL ou pré-forame), II (FLP ou trans-forame) e III (FP ou pós-forame). No estudo realizado com 803 pacientes fissurados não sindrômicos (casos novos, não operados), matriculados no HRAC, FREITAS et al. ${ }^{14}$ (2004) observaram um predomínio de pacientes com FLP $(37,1 \%)$, seguida pela FP $(31,7 \%)$ e pela FL $(28,4 \%)$. Quando comparavam os gêneros, o feminino tinha uma discreta predileção com a FP $(53 \%)$ e o masculino era mais afetado com os outros tipos de fissura (cerca de $60 \%$ ). O lado esquerdo do paciente fissurado era mais afetado que o direito nas fissuras unilaterais, numa proporção de aproximadamente 5:4.

DERIJCKE; EERENS; CARELS ${ }^{10}$ (1996) fizeram um estudo bibliométrico, em pacientes fissurados não sindrômicos, de trabalhos epidemiológicos mundiais. Os autores concluíram que além das fissuras labiopalatais mostrarem uma grande variação entre os diferentes países, existia uma alta incidência de FL/P quando comparada à FP. Havia uma predominância de garotas no grupo de pacientes com FP, enquanto que os garotos predominavam no grupo de FL/P. O lado esquerdo foi mais afetado que o direito numa proporção de 2:1.

$\mathrm{Na}$ nossa amostra, havia 13 pessoas do gênero feminino $(59,09 \%)$, destas, 7 pacientes $(53,85 \%)$ tinham FLP, três apresentavam FL e outras três tinham FP, divergindo do trabalho de FREITAS et al. ${ }^{14}$ (2004), no qual a FP era mais comum em pessoas do gênero feminino. No gênero masculino observamos 9 pacientes ao todo $(40,91 \%)$. Destes, três pacientes tinham FLP $(33,33 \%)$, outros três com FP $(33,33 \%)$ e apenas um paciente tinha FL ou não possuía fissura. A FLP tinha maior incidência quando comparada com a FP, numa proporção de 10:6. Em nosso estudo observamos também uma maior freqüência de pacientes fissurados unilateral do lado esquerdo, assim dos 11 pacientes com fissura unilateral, 7 tinham fissura do lado esquerdo $(63,64 \%)$. Estes dados corroboram com os trabalhos de DERIJCKE; EERENS; CARELS $^{10}$ (1996) e FREITAS et al. ${ }^{14}$ (2004). 


\subsection{Considerações sobre o gene IRF6}

Os pacientes portadores da VWS que tiveram seu exon mutado identificado representaram 59,09\% da amostra (13 pacientes), semelhante ao estudo de BJÖRG et al. $^{2}$ (2003) que relataram este índice em 60\%. Quando analisamos os exons 3, 4, 7 e 8 como sendo os responsáveis pela mutação do gene IRF6, obtivemos um total de 10 pacientes $(45,46 \%)$ com estas mutações. No mesmo estudo de BJÖRG et al. ${ }^{2}$ (2003) este índice chega a $82 \%$. O exon 4 foi o que teve maior número de mutação na nossa amostra com cinco pacientes $(27,27 \%)$, porém bem abaixo dos achados da literatura que é de aproximadamente $75 \%$ dos individuos com VWS. Porém, quando levamos em consideração apenas os exons mutados conhecido, este índice passa para 38,46\% da nossa amostra. Provavelmente esta discrepância se deve ao pequeno número de pacientes observados na nossa amostra e ao elevado número de pacientes que não tiveram identificado a mutação gênica (nove pacientes - 40,91\%).

\subsection{Considerações sobre xerostomia}

O único artigo que relacionou a presença de fissura e xerostomia foi escrito por MATSUDA et al. ${ }^{30}$ (1999). Neste trabalho, os autores relataram um garoto com FLP e xerostomia observada desde o nascimento. Exames complementares (tomografia computadorizada e imagens por ressonância magnética) revelaram ausência bilateral da glândula parótida, bem como ausência da glândula submandibular direita.

No nosso trabalho, seguimos a metodologia do trabalho proposto por NAVAZESH; CHRISTENSEN; BRIGHTMAN ${ }^{34}$ (1992), com algumas restrições e considerações. Segundo estes autores, a medida do fluxo salivar, sem estímulos, em um paciente normal é superior a $0,16 \mathrm{ml} / \mathrm{min}$. Assim, a cada cinco minutos, este paciente cuspiria pelo menos $0,9 \mathrm{ml}$ de saliva. A coleta foi realizada três vezes consecutivas, uma vez por semana, sempre no período das 9 horas às 15 horas. Os pacientes eram privados de alimentos e bebidas, exceto água, por duas horas antes do teste. Como nossos pacientes vinham muitas vezes de outras cidades e viajavam por várias horas, não conseguimos realizar três medidas. Assim, foi realizada apenas uma coleta, durante a própria consulta clínica. O horário também não pode ser seguido à risca, já que dependia do agendamento e da marcação da consulta. A parte de ingestão de alimentos e água também ficou prejudicada, já que os pacientes já chegavam ao HRAC alimentados, depois das longas viagens. Tivemos dificuldades também relacionadas 
com a coleta em crianças, já que em nosso estudo tivemos 9 pacientes com idade semelhante ou inferior a 8 anos. Uma delas não conseguiu realizar o teste de salivação, e foi dado um escore de valor nulo (anexo 5 - família 6). A média da coleta de salivação foi de 1,88ml/5min, acima do fluxo salivar de pacientes normofuncionais, que é de $0,9 \mathrm{ml} / 5 \mathrm{~min}$. Porém, quando levamos em consideração aqueles 5 pacientes que relataram na anamnese a presença de boca seca, quatro possuíam índice menor que $0,8 \mathrm{ml} / 5 \mathrm{~min} \mathrm{e}$ segundo NAVAZESH; CHRISTENSEN; BRIGHTMAN ${ }^{34}$ (1992) estariam enquadrados em pacientes com hiposalivação.

\subsection{Associações entre fosseta, fissura, agenesia e mutação do IRF6}

No nosso estudo, devido ao pequeno número da amostra, as mais diversas associações não puderam ser comprovadas ou descartadas, através dos testes estatísticos. O teste Fisher foi utilizado, porém em todas as associações estudadas tivemos resultados não comprobatórios. Sugerimos, então, que novos pacientes sejam avaliados para aumentar a casuística dos pacientes portadores da VWS.

\subsection{Em síntese}

A confecção e observação detalhada do pedigree familial (heredograma) pode auxiliar no diagnóstico e no aumento da incidência dos portadores da VWS. Também, é de suma importância que o cirurgião-dentista se conscientize e faça parte da equipe de aconselhamento e diagnóstico genético, já que diversas anomalias dentárias participam do fenótipo de diversas síndromes. Em particular, a VWS tem como traço marcante a agenesia dentária e segundo VAN DER WOUDE ${ }^{57}$ (1954), a ausência dentária faria parte da tríade característica da síndrome, juntamente com a presença de fosseta congênita de lábio inferior e de fissura de lábio e/ou palato. 
Conclusão 


\section{7 - CONCLUSÃO}

Considerando os resultados obtidos e observando as limitações dos métodos empregados e sua interpretação, concluímos que:

1. A agenesia dentária é um achado importante nos pacientes com a VWS. Dos 22 pacientes examinados, $10(45,45 \%)$ apresentava pelo menos ausência de um dente;

2. O dente mais comumente ausente era o segundo pré-molar (10 dentes de um total de 21 dentes ausentes na amostra - 47,62\%), seguido pelo incisivo lateral com oito ausências $(38,10 \%)$;

3. Anomalias dentárias diversas estavam presentes em 15 sujeitos desta amostra $(68,20 \%)$;

4. A sialometria média da amostra foi de $1,88 \mathrm{ml} / 5 \mathrm{~min}$ e cinco $(22,73 \%)$ pacientes disseram que apresentavam xerostomia;

5. A mutação no éxon 4 foi a mais comum desta amostra e estava presente em seis pacientes $(27,27 \%)$. Os nove pacientes $(40,91 \%)$ que não tiveram descoberta a mutação gênica provavelmente se deve a alterações gênicas intrônicas do próprio IRF6;

6. O tipo de fissura mais comum foi a FLP, com dez pacientes $(45,45 \%)$, seguida pela FP com seis $(27,27 \%)$ e a FL com quatro pacientes $(18,18 \%)$. Sete tinham fissura do lado esquerdo $(63,64 \%)$, quando analisados os onze pacientes que possuíam fissura unilateral;

7. A fosseta labial mais comum foi a bilateral, presente em 11 pacientes (50\%), seguida pela fosseta unilateral do lado direito em quatro pacientes $(18,18 \%)$. Três pacientes tinham ausência da fosseta e dois pacientes $(9,09 \%)$ possuíam ou fosseta unilateral esquerda ou fosseta única;

8. As associações entre agenesia, tipo de fissura, mutação e fosseta não puderam ser estatisticamente consideradas, provavelmente devido ao número de pacientes examinados neste estudo;

9. Mutações no gene IRF6 podem também contribuir para anomalias do desenvolvimento de órgãos e tecidos de origem ectodérmica.

A partir destas conclusões, sugerimos que outros trabalhos sejam realizados para ampliar os entendimentos gerais e bucais da VWS e que novos estudos sejam 
direcionados para correlacionar as mutações genéticas com as mais diversas variações fenotípicas desta síndrome. 


\section{Anexos}


ANEXO 1 - Parecer do Comitê de Ética em Pesquisa do HRAC-USP, aprovando a realização deste estudo

Oficio $n^{*}$ 29012005-UEP.CEP

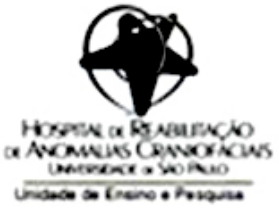

Bauru, 31 de outubro \& 2005

Prezado(a) Senhor(a)

O projeto de pesquisa encaminhado a cste Comitê de Êtica em Pesquisa em Seres Humanos. denominado "Caracterizagáo clinica, radiográfica e molecular $\mathrm{em}$ pacientes com sindrome de Van der Woude (VWS)". de autoria de CARLOS HENRIQUE BETTONI CRUZ DE CASTRO desenvolvido sob sua co-orientay lo, foi enviado ao relator para avaliaylo.

O parecer do relator, aprovando o projeto, foi aceito pelo Comitê, considerando que năo existem infracóes cticas pendentes para inkio da pesquisa. Solicitamos a V.SP a gentileza de coenunicar o parecer ao prsquisador.

O pesquisador fica responsuvel pela entrega na Unidade de Ensirso e Pesquisa dos relatórios semestrais, bem como comunicar ao CEP todas as alteraçét que possam ocoerer no projeto.

Informamos que após o recebimento do trabalho concluido. este Comitê enviará o parecer final para publicacjo.

Atenciosamente

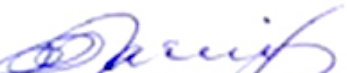

PROF. DR. ROPERTO LOUREIROMLARINGONI

Coordenador do Comitê de Exica em Pesquisa do HRAC.USP

Ilmora) Srf(a)

Dr. Antonio Richicri-Costa

Genttica - HRACIUSP

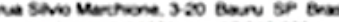


ANEXO 2 - Carta de Informação ao Sujeito da Pesquisa

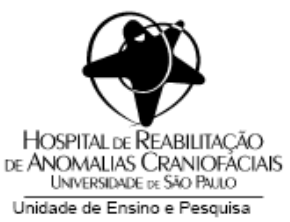

\title{
CARTA DE INFORMAÇÃO AO SUJEITO DA PESQUISA
}

\begin{abstract}
Nós estamos convidando você a participar de uma pesquisa do Serviço de Aconselhamento Genético, do Hospital de Reabilitação das Anomalias Craniofaciais - "Centrinho", juntamente com o Departamento de Patologia da Faculdade de Odontologia de Bauru, da Universidade de São Paulo, intitulada: "CARACTERIZACCÃO CLÍNICA, RADIOGRÁFICA E MOLECULAR EM PACIENTES COM SÍNDROME DE VAN DER WOUDE (VWS)". Este trabalho analisará os pacientes portadores da Sindrome de Van der Woude, no seu aspecto clínico, radiográfico e molecular.

Se vocês decidirem participar desta pesquisa, gostariamos de informar-lhes que:

1. Os resultados deste estudo talvez não sejam de benefício imediato para você e sua família;

2. Vocês estarão colaborando para aumentar nosso conhecimento sobre a Sindrome de Van der Woude;

3. Utilizaremos de exames clínicos e fotografias, além das avaliações radiográfica e molecular já realizada, para podermos avaliar o tipo de fissura, a quantidade de dentes presentes e ausentes e suas características e a quantidade de saliva produzida durante o exame. Os desconfortos e os riscos são os mesmos de uma consulta clínica odontológica de rotina.

4. Os resultados poderão demorar meses para ficarem prontos;

5. Assim que existam resultados, estes serão apresentados a você ou seu representante legal pelo Dr. Carlos Henrique Bettoni Cruz de Castro;

6. Os resultados deverão ser apresentados em jornadas e publicados em revistas cientificas que circulam entre os profissionais da saúde que tenham interesse nesta área;

7. Sempre que ocorrerem apresentações ou publicações cientificas, a identidade do paciente e de sua familia será mantida em sigilo absoluto;

8. Todos os resultados dos exames estarão disponiveis no prontuário do paciente do Hospital de Reabilitação das Anomalias Craniofaciais - HRAC USP;

9. Caso o sujeito da pesquisa queira apresentar reclamações em relação a sua participação na pesquisa, poderá entrar em contato com o Comitê de Ética em Pesquisa em Seres Humanos, do HRAC-USP, pelo endereço Rua Silvio Marchione, 3-20 na Unidade de Ensino e Pesquisa ou pelo telefone (14) $3235-8421$.

10. Em casos de danos que se justifiquem, o sujeito da pesquisa tem à sua disposição tratamento odonto- médico e a indenização a que legalmente tenha direito, por parte do HRAC-USP e FOBUSP, diretamente causados pela pesquisa, com nexo causal comprovado.

11. Se existirem gastos adicionais, estes serão absorvidos pelo orçamento da pesquisa.

Recebi as informações referentes aos procedimentos através do Cirurgião Dentista Carlos Henrique Bettoni Cruz de Castro, junto com convite para participar da pesquisa e garantia de sigilo, reconhecendo a relevância de cunho cientifico por ele realizado. Diante dos esclarecimentos concordo em participar dessa pesquisa e que não causará nenhum dano a minha pessoa.
\end{abstract}

Por estarem de acordo assinam o presente termo;

Bauru-SP, de de

Nome do sujeito ou responsável:

Assinatura do sujeito ou responsável:

Pesquisador responsável: Carlos Henrique Bettoni Cruz de Castro

Assinatura do pesquisador: 
ANEXO 3 - Termo de Consentimento Livre e Esclarecido

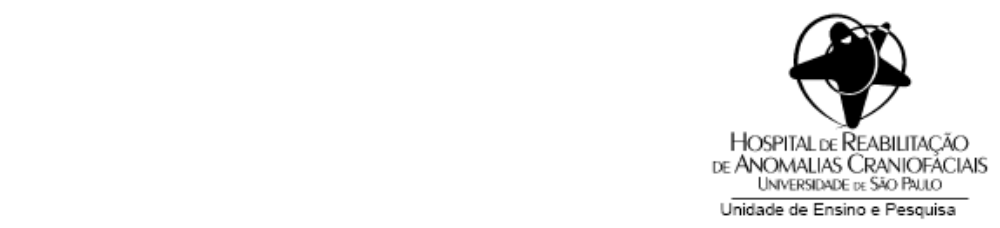

TERMO DE CONSENTIMENTO LIVRE E ESCLARECIDO

Pelo presente instrumento que atende às exigências legais, $\circ \mathrm{Sr}$.

(a)

portador da cédula de identidade

após leitura minuciosa da

CARTA DE INFORMAÇÃO AO SUJEITO DA PESQUISA, devidamente explicada pelos profissionais em seus mínimos detalhes, ciente dos serviços e procedimentos aos quais será submetido, não restando quaisquer dúvidas a respeito do lido e explicado, firma seu CONSENTIMENTO LIVRE E ESCLARECIDO concordando em participar da pesquisa: "CARACTERIZAÇÃO CLÍNICA, RADIOGRÁFICA E MOLECULAR EM PACIENTES COM SÍNDROME DE VAN DER WOUDE (VWS)", realizada por Carlos Henrique Bettoni Cruz de Castro, n ${ }^{\circ}$ CRO-MG 19.939 e sob orientação do Dr. Alberto Consolaro, $n^{\circ}$ CRO-SP 20.875 .

Fica claro que o sujeito da pesquisa ou seu representante legal, pode a qualquer momento retirar seu CONSENTIMENTO LIVRE E ESCLARECIDO e deixar de participar desta pesquisa e ciente de que todas as informações prestadas tomaram-se confidenciais e guardadas por força de sigilo profissional (Art. $9^{\circ}$ do Código de Ética Odontológica ou Art. $29^{\circ}$ do Código de Ética do Fonoaudiólogo)

Por estarem de acordo assinam o presente termo.

Bauru-SP, de de .

Nome do pesquisador: Carlos Henrique Bettoni Cruz de Castro

Endereço: Rua José Ferreira Maques, 10-41 apto 402

Cidade: Bauru - Estado: SP - CEP: 17.044-570

Telefone: (14) 3234-4317 - E-mail: carlosbettoni@usp.br

Endereço Institucional: Rua Sílvio Marchione, 3-20

Cidade: Bauru - Estado: SP - CEP: 17.012-900

Telefone: (14) 3235-8084

rua Silvio Marchione, 3-20 Bauru SP Brasil caixa postal 1501 cep $17.043-900$

e-mail: anag@usp.br 
ANEXO 4 - Ficha clínica utilizada para exame e avaliação dos pacientes

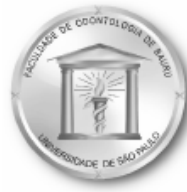

\section{Universidade de São Paulo}

Faculdade de Odontologia de Bauru

A1. Dr. Octávio Pinheiro Brisolla, 9-75 - Bauru-SP -

CEP 17012-901 - Cx.Postal. 73

PABX (0XX14)235-8000 - FAX (0XX14)223-4679

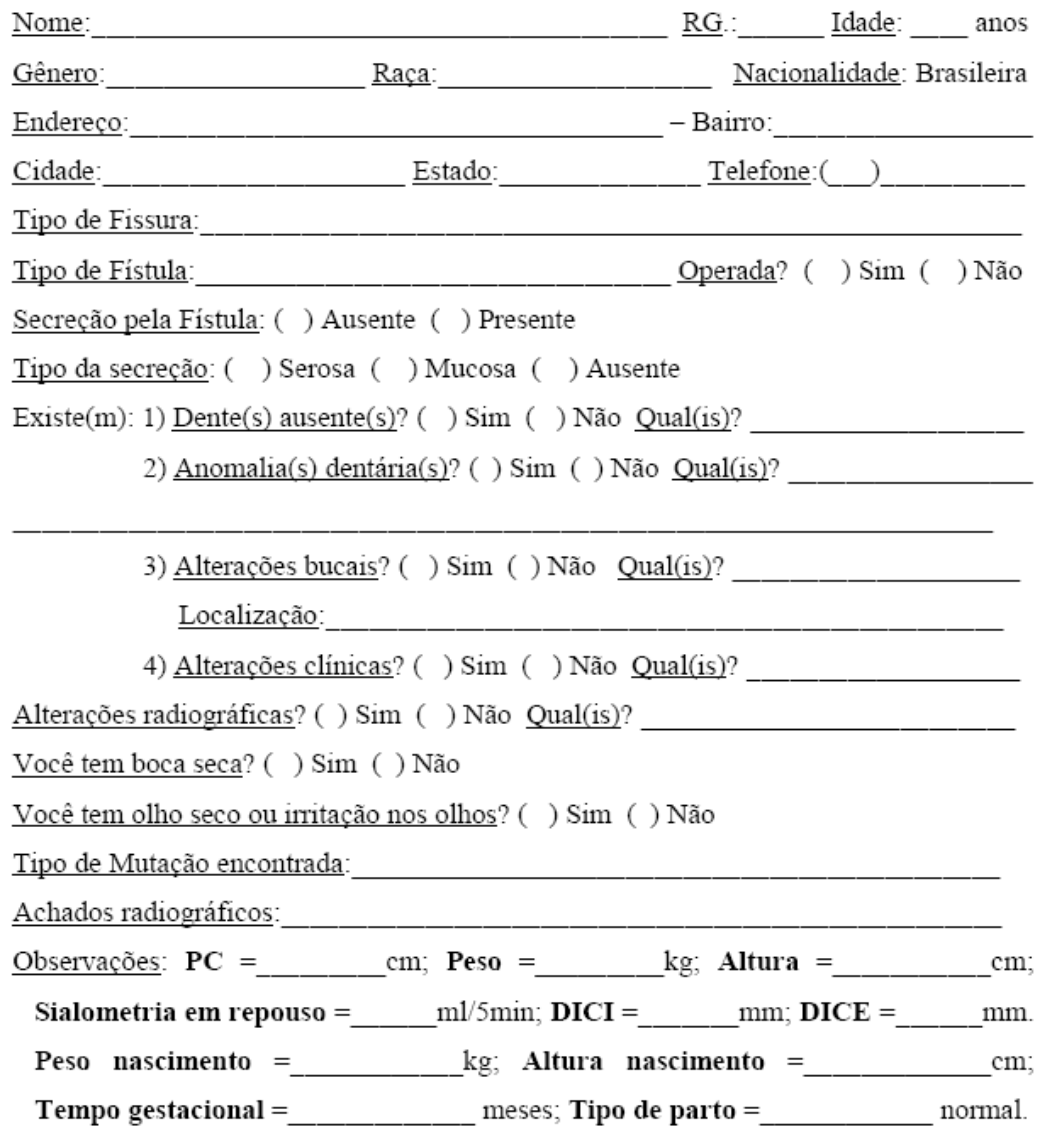

Heredrograma: 
ANEXO 5 - Heredogramas das dezesseis famílias avaliadas
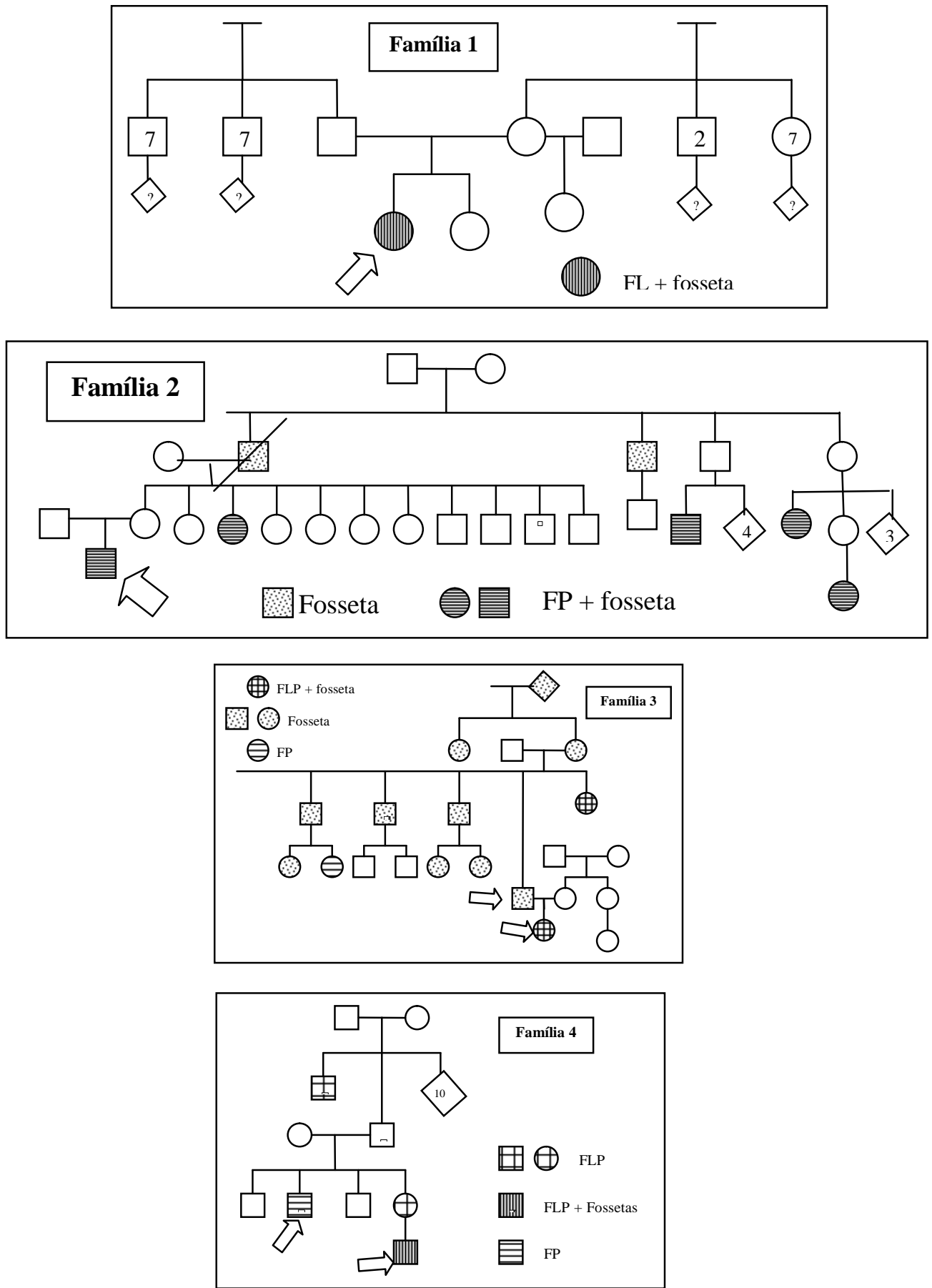

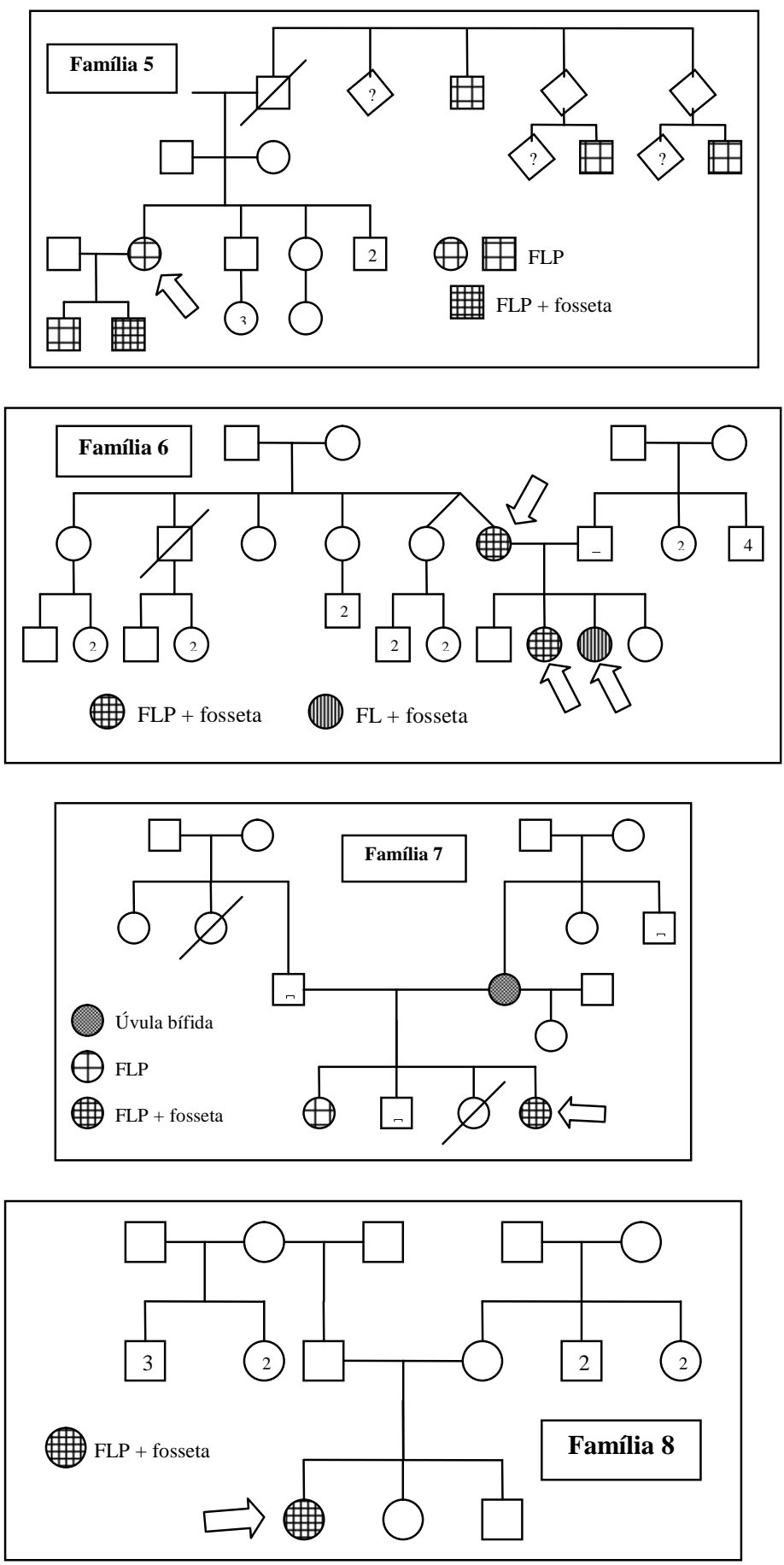

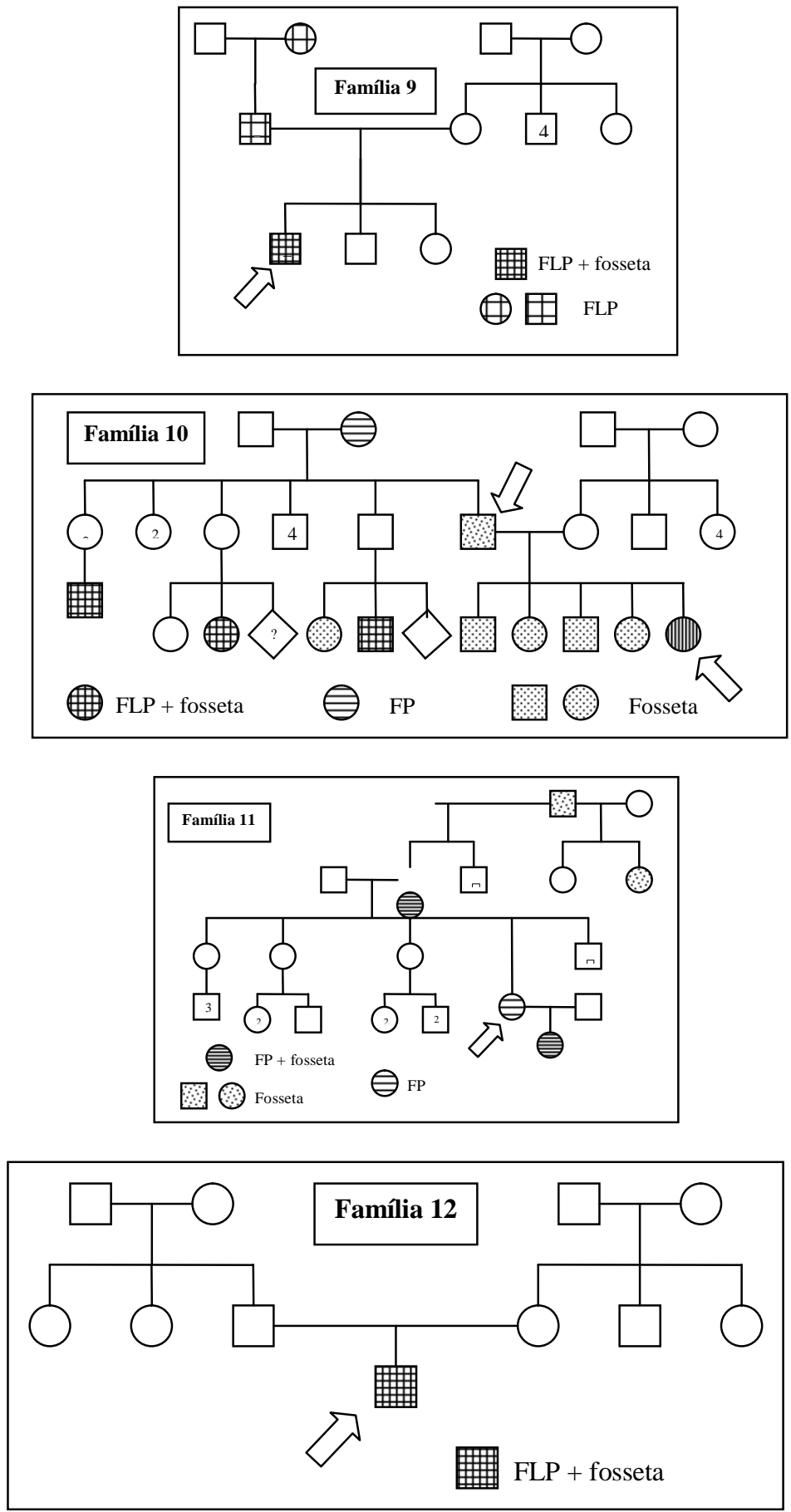

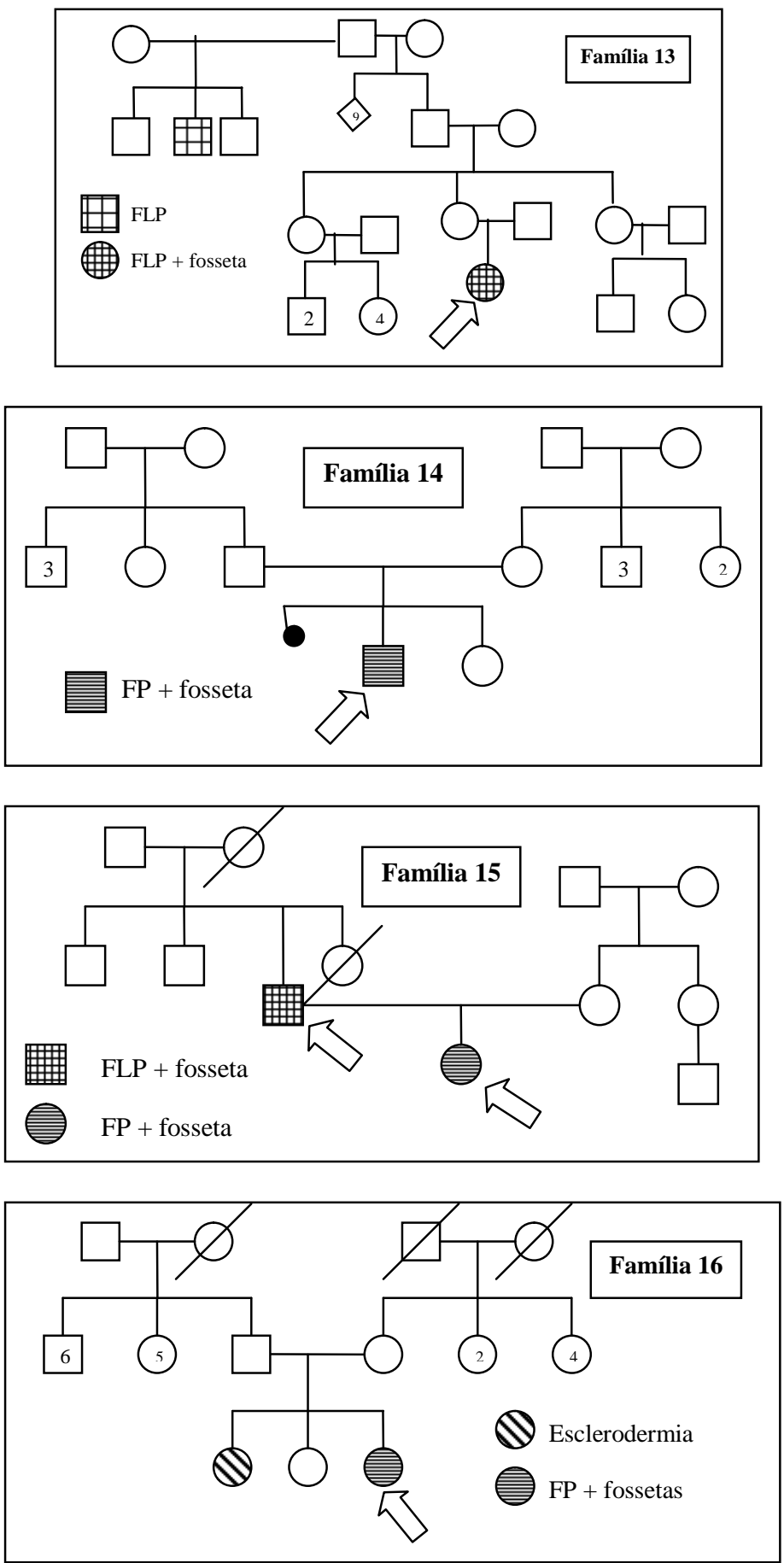
ANEXO 6 - Distribuição dos achados clínicos e radiográficos da amostra. Legendas: D, direito; E, esquerdo; N, não; S, sim, A, ausente; FL, fissura de lábio; FLP, fissura de lábio e palato; FP, fissura de palato; F, feminino; M, masculino; $\mathbf{B}$, branca; N, negra; P, parda; ?, desconhedido; ??, não soube informar.

\begin{tabular}{|c|c|c|c|c|c|c|c|c|c|c|c|c|}
\hline FAMÍLIA & IDADE & FOSSETA & $\begin{array}{l}\text { FOSSETA } \\
\text { OPERADA }\end{array}$ & FISSURA & SIALOMETRIA & GENERO & RAÇA & AGENESIA & $\begin{array}{l}\text { BOCA } \\
\text { SECA }\end{array}$ & $\begin{array}{l}\text { OLHO } \\
\text { SECO }\end{array}$ & $\begin{array}{c}\text { SECREÇÃO } \\
\text { FOSSETA }\end{array}$ & MUTAÇÃO \\
\hline I & 19 & Única & $\mathrm{N}$ & FLE & 1,2 & $\mathrm{~F}$ & $\mathrm{~B}$ & 21 & $\mathrm{~N}$ & $\mathrm{~N}$ & $\mathrm{~S}$ & 9 \\
\hline II & 5 & Bilateral & $\mathrm{N}$ & FP & 0,4 & $\mathrm{M}$ & $\mathrm{B}$ & 42 & $\mathrm{~N}$ & $\mathrm{~N}$ & $\mathrm{~N}$ & $?$ \\
\hline III & 5 & Única & $\mathrm{N}$ & FLPE & 3 & $\mathrm{~F}$ & $B$ & 21 & $\mathrm{~N}$ & $S$ & $\mathrm{~N}$ & $?$ \\
\hline III & 34 & Bilateral & $\mathrm{N}$ & Ausente & 3,1 & $M$ & $B$ & $15,22,25,45,35$ & $\mathrm{~N}$ & $\mathrm{~N}$ & $\mathrm{~N}$ & $?$ \\
\hline IV & 35 & Ausente & $A$ & $\mathrm{FP}$ & 1,8 & $M$ & $\mathrm{P}$ & Ausente & $\mathrm{N}$ & $\mathrm{N}$ & A & $?$ \\
\hline IV & 7 & Bilateral & $\mathrm{N}$ & FLPD & 2,1 & $M$ & $\mathrm{~B}$ & Ausente & $\mathrm{N}$ & $\mathrm{N}$ & $\mathrm{S}$ & 3 \\
\hline V & 29 & Ausente & $A$ & FLPE & 2,1 & $\mathrm{~F}$ & $\mathrm{P}$ & Ausente & $\mathrm{N}$ & $\mathrm{N}$ & $A$ & 7 \\
\hline VI & 34 & Unilateral D & $\mathrm{N}$ & FLPE & 0,8 & $\mathrm{~F}$ & $B$ & Ausente & $S$ & $S$ & $\mathrm{~N}$ & 4 \\
\hline VI & 10 & Unilateral D & $S$ & $\mathrm{FL}$ & 3,2 & $\mathrm{~F}$ & $B$ & Ausente & $S$ & $S$ & $\mathrm{~S}$ & 4 \\
\hline VI & 8 & Unilateral D & $S$ & FLPE & 0 & $\mathrm{~F}$ & $\mathrm{P}$ & 23,45 & $S$ & $\mathrm{~N}$ & $\mathrm{~N}$ & 4 \\
\hline VII & 8 & Bilateral & $\mathrm{N}$ & FLP & 1,6 & $\mathrm{~F}$ & $\mathrm{~N}$ & $12,22,45$ & $\mathrm{~N}$ & $\mathrm{~N}$ & $\mathrm{~S}$ & $?$ \\
\hline VIII & 12 & Unilateral E & $S$ & FLPD & 2,8 & $\mathrm{~F}$ & $B$ & Ausente & $\mathrm{N}$ & $\mathrm{N}$ & $\mathrm{S}$ & 3 \\
\hline IX & 9 & Bilateral & $S$ & FLPE & 3 & $M$ & $P$ & Ausente & $\mathrm{N}$ & $\mathrm{N}$ & $\mathrm{N}$ & 7 \\
\hline$X$ & 8 & Unilateral D & $\mathrm{N}$ & $\mathrm{FL}$ & 0,8 & $\mathrm{~F}$ & $\mathrm{P}$ & 25 & $S$ & $\mathrm{~N}$ & $S$ & 4 \\
\hline$X$ & 48 & Bilateral & $\mathrm{N}$ & Ausente & 2,4 & $M$ & $B$ & Ausente & $\mathrm{N}$ & $\mathrm{N}$ & $\mathrm{S}$ & 4 \\
\hline $\mathbf{X I}$ & 26 & Ausente & $A$ & $\mathrm{FP}$ & 0,6 & $\mathrm{~F}$ & $P$ & Ausente & $S$ & $\mathrm{~N}$ & $A$ & $?$ \\
\hline XII & 7 & Bilateral & $S$ & FLD & 2,6 & $M$ & $\mathrm{~B}$ & Ausente & $\mathrm{N}$ & $\mathrm{N}$ & $? ?$ & 4 \\
\hline XIII & 8 & Bilateral & $S$ & FLPE & 1,4 & $\mathrm{~F}$ & $B$ & 45 & $\mathrm{~N}$ & $\mathrm{~N}$ & $\mathrm{~S}$ & $?$ \\
\hline XIV & 8 & Bilateral & $S$ & $\mathrm{FP}$ & 2,6 & $\mathrm{M}$ & $\mathrm{P}$ & Ausente & $\mathrm{N}$ & $\mathrm{N}$ & $\mathrm{S}$ & 1 \\
\hline $\mathrm{XV}$ & 30 & Unilateral E & $\mathrm{N}$ & FLPD & 1,9 & $\mathrm{M}$ & $B$ & 12,22 & $\mathrm{~N}$ & $\mathrm{~N}$ & $\mathrm{~N}$ & $?$ \\
\hline XV & 11 & Bilateral & $\mathrm{N}$ & FP & 1,9 & $\mathrm{~F}$ & $B$ & $12,22,35,45$ & $\mathrm{~N}$ & $\mathrm{~N}$ & $\mathrm{~N}$ & 6 \\
\hline XVI & 17 & Bilateral & $\mathrm{N}$ & FP & 2 & $\mathrm{~F}$ & $\mathrm{~B}$ & Ausente & $\mathrm{N}$ & $\mathrm{N}$ & $\mathrm{N}$ & $?$ \\
\hline
\end{tabular}


ANEXO 7 - Continuação da distribuição dos achados clínicos e radiográficos da amostra. Legendas: ??, não soube informar

\begin{tabular}{|c|c|c|c|c|c|c|c|c|c|c|}
\hline FAMÍLIA & $\begin{array}{l}\text { PESO } \\
\text { NASC }\end{array}$ & $\begin{array}{c}\text { ALT } \\
\text { NASC }\end{array}$ & PC & PESO & ALTURA & PARTO & GESTAÇÃO & DICl & DICE & ANOMALIAS DENTÁRIAS \\
\hline I & $? ?$ & $? ?$ & 54,5 & 51,6 & 1,66 & $\mathrm{~N}$ & 9 & 31,95 & 89,13 & Dente 25 retido \\
\hline II & 2620 & 48 & 53,5 & 20,3 & 1,13 & $\mathrm{~N}$ & 8 & 28,62 & 78,78 & Dente 82 conóide \\
\hline III & 2640 & 47 & 52 & 17,5 & 1,12 & $\mathrm{C}$ & 8 & 28,2 & 74,1 & Hipoplasia 63, 64, 65 \\
\hline III & $? ?$ & $? ?$ & 57 & 76,5 & 1,64 & $? ?$ & 7 & 32,99 & 85,22 & Microdontia 12, 13, 33, 43 \\
\hline IV & $? ?$ & $? ?$ & 56,5 & 64,5 & 1,62 & ?? & $? ?$ & 36,9 & 93,77 & - \\
\hline IV & 2710 & 47,5 & 52 & 24,6 & 1,25 & $\mathrm{~N}$ & 9 & 32,67 & 83,81 & - \\
\hline V & $? ?$ & $? ?$ & 61 & 107 & 1,67 & $\mathrm{~N}$ & 9 & 36,4 & 98,89 & - \\
\hline V & $? ?$ & ?? & 56 & 43,5 & 1,56 & $\mathrm{C}$ & 9 & 42,24 & 87,76 & Hipoplasia generalizada \\
\hline VI & 2580 & 47 & 54 & 31,5 & 1,4 & $\mathrm{~N}$ & 8 & 31 & 76,04 & Hipoplasia 11 e 21 \\
\hline VI & 2800 & 47,5 & 52 & 23,5 & 1,27 & $\mathrm{~N}$ & 8 & 31,86 & 77,45 & Hipoplasia 41 \\
\hline VII & 3010 & 48 & 53 & 24,3 & 1,28 & $\mathrm{~N}$ & 9 & 33,53 & 84,56 & Microdontia 21 \\
\hline VIII & 3580 & 49 & 55,5 & 48,8 & 1,63 & $\mathrm{C}$ & 9 & 29,74 & 77,57 & $4^{\circ}$ molar superior esquerdo \\
\hline IX & 3950 & 49 & 52 & 31,8 & 1,35 & $\mathrm{~N}$ & 9 & 33,64 & 86,29 & Atraso odontogênese 45 \\
\hline $\mathbf{X}$ & 2670 & $? ?$ & 52 & 22,3 & 1,28 & $\mathrm{~N}$ & 9 & 32,85 & 81,66 & - \\
\hline $\mathbf{X}$ & $? ?$ & $? ?$ & 59 & 96,5 & 1,66 & $\mathrm{~N}$ & 9 & 39,36 & 88,21 & - \\
\hline $\mathbf{X I}$ & $? ?$ & $? ?$ & 57 & 68 & 1,52 & $\mathrm{~N}$ & 9 & 33,96 & 87,95 & - \\
\hline XII & 2970 & 49 & 56 & 23,4 & 1,29 & $\mathrm{C}$ & 9 & 31,8 & 82,26 & Molares com cúspides baixas \\
\hline XIII & 3180 & 51 & 52 & 25 & 1,3 & $\mathrm{C}$ & 9 & 29,23 & 80,18 & Molares com cúspides baixas \\
\hline XIV & 3580 & 49 & 52 & 22,5 & 1,24 & $\mathrm{C}$ & 9 & 31,32 & 84,23 & - \\
\hline $\mathbf{X V}$ & 3300 & 47 & 59 & 74,9 & 1,6 & $\mathrm{~N}$ & 9 & 31,74 & 90,78 & Hiperdontia 11 e 21 \\
\hline $\mathbf{X V}$ & 3400 & 47 & 54 & 42,5 & 1,51 & $\mathrm{~N}$ & 9 & 27,4 & 87,62 & $\begin{array}{c}\text { Atraso esfoliação dentária } \\
(52,53,63)\end{array}$ \\
\hline $\mathbf{X V I}$ & 2400 & $? ?$ & 54,5 & 53,7 & 1,72 & $\mathrm{C}$ & 9 & 32,49 & 84,39 & Microdontia 31 \\
\hline
\end{tabular}


ANEXO 8 - Gráfico do tipo Boxplots, das variáveis numéricas, idade; sialometria; peso e altura ao nascimento; distância cefálica; peso; altura; distância intercantal interna e externa
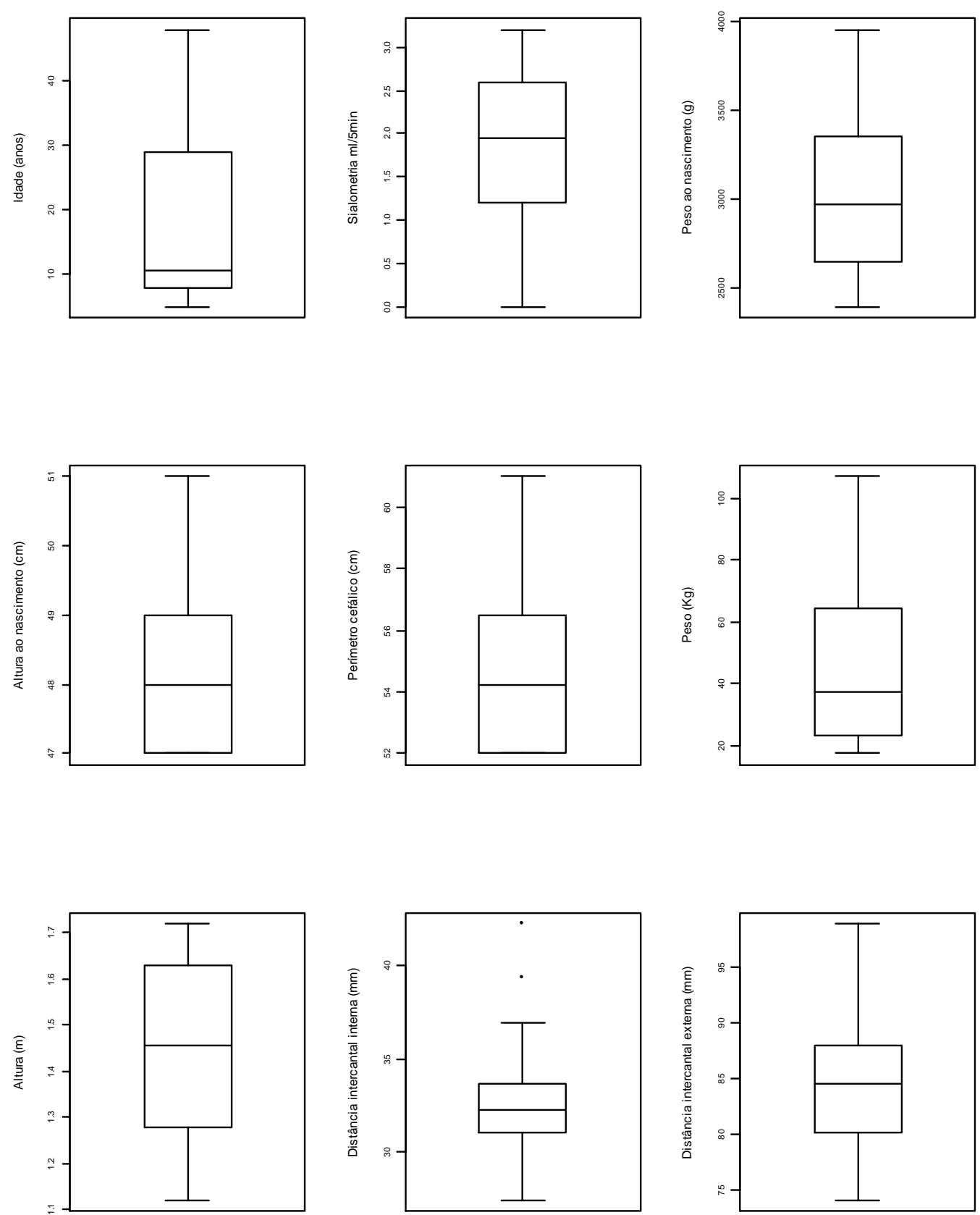
ANEXO 9 - Gráfico do tipo média \pm 2EP (erro-padrão), das variáveis numéricas, idade; sialometria; peso e altura ao nascimento; distância cefálica; peso; altura; distância intercantal interna e externa
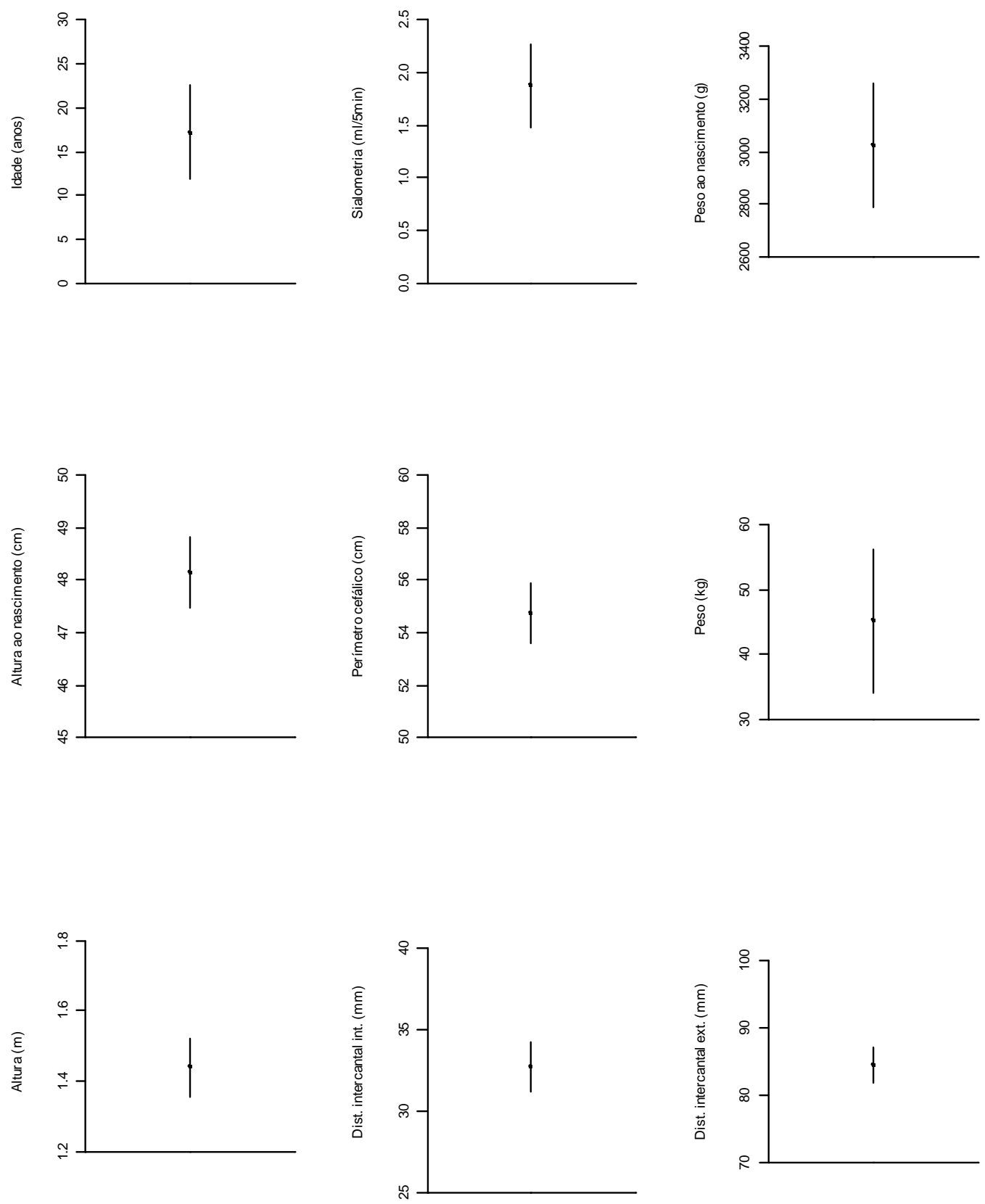
ReferênCI AS Bi bli OGRÁficAS 


\section{REFERÊNCIAS BIBLIOGRÁFICAS}

1. BATRA P, DUGGAL R, PARKASH H. Genetics of cleft lip and palate revisited. J Clin Pediatr Dent. 2003 Summer; 27(4):311-20.

2. BJORK BC, KRAHN KN, SCHUTTE BC, MURRAY JC. IRF6-Related Disorders. [homepage na Internet]. Washington: Gene Reviews; 2006 May [Acesso em: 12 set.]. Disponível em: http://www.geneclinics.org/profiles/vws.

3. BOCIAN M, WALKER AP. Lip pits and deletion 1q32à 41. Am J Med Genet. 1987 Feb;26(2):437-43.

4. BOWERS DG. Surgical repair of congenital lower lip sinuses. Plast Reconstr Surg. 1972 Jun;49(6):632-6.

\section{CASTRO CHB, FREITAS PZ, ANTONELI MZ, SANTIAGO G, RIBEIRO} LA, RICHIERI-COSTA A. Periventricular neuronal heterotopia, oro-faciodigital anomalies, and microphthalmia. A new syndrome? Clin. Dysmorphol. 2005 Oct;14(4):197-201.

6. CERVENKA J, GORLIN RJ, ANDERSON VE. The syndrome of pits of the lower lip and cleft lip and/or palate. Genetic considerations. Am J Hum Genet. 1967 May;19(3):416-32.

7. COBOURNE MT. The complex genetics of cleft lip and palate. Eur J Orthod. $2004 \mathrm{Feb} ; 26(1): 7-16$.

8. CUERVO R, COVARRUBIAS L. Death is the major fate of medial edge epithelial cells and the cause of basal lamina degradation during palatogenesis. Development. 2004 Jan;131(1):15-24.

9. DENION E, CAPON N, MARTINOT V, PELLERIN P. Neonatal permanent jaw constriction because of oral synechiae and Pierre Robin sequence in a child with Van der Woude Syndrome. Cleft Palate Craniofac J. 2002 Jan ;39(1):115-9.

10. DERIJCKE A, EERENS A, CARELS C. The incidence of oral clefts: a review. Br J Oral Maxillofac Surg. 1996 Dec;34(6):488-94.

11. DUDAS M, LI WY, KIM J, YANG A, KAARTINEN. Palatal fusion - Where do the midline cells go? A review on cleft, a major human birth defect. Acta Histochem. 2006 Sept 6; [Epub ahead of print].

12. EERENS K, VLIETINCK R, HEIDBUCHEL K, VAN OLMEN A, DEROM C, WILLEMS G, et al. Hypodontia and tooth formation in groups of childrenwith 
cleft, siblings without cleft, and nonrelated controls. Cleft Palate Craniofac J. $2001 \mathrm{Jul} ; 38(4): 374-8$.

13. FERGUSON MW. The mechanism of palatal shelf elevation and the pathogenesis of cleft palate. Virchows Arch A Pathol Anat Histol. 1977 Aug;375(2):97-113.

14. FREITAS JAS, DALBEN GS, SANTAMARIA JR M, FREITAS PZ. Current data on the characterization of oral clefts in Brazil. Braz Oral Res. 2004 AprJun;18(2):128-33.

15. GORLIN RJ, COHEN MM, LEVIN LS. Van der Woude Syndrome (cleft lippalate and paramedian sinuses of the lower lip). In: Syndromes of the Head and Neck. Oxford: Univ Press; 1990. p. 738-740.

16. HARADA Y, ISHIZEKI K. Evidence for transformation of chondrocytes and site-specific resorption during the degradation of Meckel's cartilage. Anat Embryol. 1998 Jun;197(6):439-50.

17. ICHIKAWA E, WATANABE A, NAKANO Y, AKITA S, HIRANO A, KINOSHITA A, et al. PAX9 and TGFB3 are linked to susceptibility to nonsyndromic cleft lip with or without cleft palate in the Japanese: populationbased and family-based candidate gene analyses. J Hum Genet. 2006;51(1):3846.

18. INGRAHAM CR, KINOSHITA A, KONDO S, YANG B, SAJAN S, TROUT $\mathrm{KJ}$, et al. Abnormal skin, limb and craniofacial morphogenesis in mice deficient for interferon regulatory factor 6 (Irf6). Nat Genet. 2006 Nov;38(11):1335-40.

19. JIROUTOVA O, MULLEROVA Z. The occurrence of hypodontia in patients with cleft lip and/or palate. Acta Chir Plast. 1994;36(2):53-6.

20. KARSTEN A, LARSON M. The relationship between hypodontia in the second premolar region and heredity of cleft, lip and palate in children with isolated cleft palate. Swed Dent J. 2004;28(1):47-52.

21. KARSTEN A, LARSON M, LARSON O. Length of the cleft in relation to the incidence of hypodontia of the second premolar and to inheritance of cleft lip and palate in children with isolated cleft palate. Scand J Plast Reconstr Surg Hand Surg. 2005;39(5):283-6.

22. KONDO S, SCHUTTE BC, RICHARDSON RJ, BJORK BC, KNIGHT AS, WATANABE Y S, et al. Mutations in IRF6 cause Van der Woude and popliteal pterygium syndromes. Nat Genet. 2002 Oct;32(2):285-9. 
23. KROST B, SCHUBERT J. Influence of season on prevalence of cleft lip and palate. Int J Oral Maxillofac Surg. 2006 Mar;35(3):215-8.

24. LACOMBE D, PEDESPAN JM, FONTAN D, CHATEIL JF, VERLOES A. Phenotypic variability in van der Woude Syndrome. Genetic Counseling.1995;6(3): 221-6.

25. LEES MM, WINTER RM, MALCOLM S, HOWARD MS, CHITTY L. Popliteal pterygium syndrome: a clinical study of three families and report of linkage to the Van der Woude syndrome locus on 1q32. J Med Genet. 1999 Dec;36(12):888-92.

26. LIDRAL AC, REISING BC. The role of MSX1 in human tooth agenesis. J Dent Res. 2002 Apr;81(4):274-8.

27. LIMA RLLFV. Estudo do gene IRF6 em portadores da síndrome de Van der Woude [tese]. Botucatu: Universidade Estadual Paulista. Curso de Ciências Biológicas. Departamento de Genética, 2005.

28. LOHOFF M, MAK TW. Roles of interferon-regulatory factors in T-helper-cell differentiation. Nat Rev Immunol. 2005 Feb;5(2):125-35.

29. MANSILLA MA, COOPER ME, GOLDSTEIN T, CASTILLA EE, LOPEZ CAMELO JS, MARAZITA ML, et al. Contributions of PTCH gene variants to isolated cleft lip and palate. Cleft Palate Craniofac J. 2006 Jan;43(1):21-9.

30. MATSUDA C, MATSUI Y, OHNO K, MICHI K. Salivary gland aplasia with cleft lip and palate. Oral Surg Oral Med Oral Pathol Oral Radiol Endod. 1999 Мay;87(5):594-9.

31. MÖHRENSCHLAGER M, RING J, ABECK D. Further aspects of Van der Woude Syndrome (congenital lower lip pits). Pediatric Dermatol. 2004 JanFeb;21(1):92.

32. MURRAY JC, NISHIMURA DY, BUETOW KH, ARDINGER HH, SPENCE MA, SPARKES RS, et al. Linkage of an autosomal dominant clefting syndrome (Van der Woude) to loci on chromosome Iq. Am J Hum Genet. 1990 Mar;46(3):486-91.

33. MURRAY JC. Gene/environment causes of cleft lip and/or palate. Clin Genet. 2002 Apr;61(4):248-56.

34. NAVAZESH M, CHRISTENSEN C, BRIGHTMAN V. Clinical criteria for the diagnosis of salivary gland hypofunction. J Dent Res. 1992 Jul;71(7):1363-9. 
35. OBEROI S, VARGERVIK K. Hypoplasia and hipodontia in Van der Woude syndrome. Cleft Palate Craniof J. 2005 Sept;42(5):459-66.

36. OBREGON MG, IWANYK P, NEGROTTI T. Importancia de las fositas del labio inferior en niños con fisura labio-palatina. Arch Argent Pediatr. 1999 Oct;97(5):345-8.

37. ONOFRE M. Estudo histopatológico das fístulas de lábio inferior em portadores da Síndrome de Van der Woude [dissertação]. Bauru: Universidade de são Paulo. Curso de Odontologia. Departamento de Diagnóstico Oral, 1987.

38. ONOFRE MA, TAGA R. Fístulas congênitas de lábio inferior na Síndrome de Van der Woude. Uma revisão. Rev FOB. 1994 Abr-Jun;2(2):35-41.

39. ONOFRE MA, BROSCO HB, TAGA R. Relationship between lower-lip fistulae and cleft lip and/or palate in Van der Woude Syndrome. Cleft Palate Craniof J. 1997 May;34(3):261-5.

40. ONOFRE MA, BROSCO HB, TAGA R. Ultrastructural analysis of glands located in the wall of the congenital fistulae of the lower lip of patients with Van der Woude syndrome. J Appl Oral Sci. 2003 Jul-Sept;11(3):198-202.

41. PRESCOTT NJ, WINTER RM, MALCOLM S. Nonsyndromic cleft lip and palate: complex genetics and environmental effects. Ann Hum Genet. 2001 Nov;65(6):505-15.

42. PUVABANDITSIN S, GARROW E, SITBURANA O, AVILA FM, NABONG MY, BISWAS A. Syngnathia and Van der Woude Syndrome: a case report and literature review. Cleft Palate Craniofac J. 2003 Jan;40(1):104-6.

43. RANTA R, RINTALA A. Tooth anomalies associated with congenital sinuses of the lower lip and cleft lip/palate. Angle Orthod. 1982 Jul;52(3):212-21.

44. RANTA R, RINTALA AE. Correlations between microforms of the Van der Woude Syndrome and cleft palate. Cleft Palate J. 1983 Apr;20(2):158-62.

45. RICHARDSON RJ, DIXON J, MALHOTRA S, HARDMAN MJ, KNOWLES L, BOOT-HANDFORD RP, et al. Irf6 is a key determinant of the keratinocyte proliferation-differentiation switch. Nat Genet. 2006 Nov;38(11):1329-34.

46. RINTALA A, LAHTI A. On so-called median lower lip sinuses. Scand J Plast Reconstr Surg. 1973;7:78-80.

47. RINTALA A, RANTA R. Lower lip sinuses: I. Epidemiology, microforms and transverse sulci. Br J Plast Palate Surg. 1981 Jan;34:26-30. 
48. RIZOS M, SPYROPOULOS MN. Van der Woude syndrome: a review. Cardinal signs, epidemiology, associated features, differential diagnosis, expressivity, genetic counselling and treatment. Eur J Orthod. 2004 Feb;26(1):17-24.

49. SCHUTTE BC, MURRAY JC. The many faces and factors of orofacial clefts. Hum Mol Genet. 1999 Sept;8(10):1853-9.

50. SLAYTON RL, WILLIAMS L, MURRAY JC, WHEELER JJ, LIDRAL AC, NISHIMURA CJ. Genetic association studies of cleft lip and/or palate with hypodontia outside the cleft region. Cleft Palate Craniofac J. 2003 May;40(3):274-9.

51. SHPRINTZEN RJ, GOLDBERG RB, SIDOTI EJ. The penetrance and variable expression of the van der Woude syndrome: Implications for genetic counseling. Cleft Palate J. 1980 Jan;17(1):52-57.

52. SPINA V, PSILLAKIS J,LAPA FS, FERREIRA MC. Classificação das fissuras lábio-palatais. Sugestão de modificação. Rev Hosp Clin Fac Med S Paulo. 1972;27(1):5-6.

53. TANIGUCHI T, OGASAWARA K, TAKAOKA A, TANAKA N. IRF family of transcription factors as regulators of host defense. Annu Rev Immunol. 2001;19:623-55.

54. TEN CATE AR. Embriologia geral. In: Ten Cate AR. Histologia Bucal Desenvolvimento, Estrutura e Função. Rio de Janeiro: Guanabara Koogan; 2001. p.10-23.

55. TEN CATE, AR. Embriologia da cabeça, face e cavidade oral. "In": Ten Cate AR. Histologia Bucal - Desenvolvimento, Estrutura e Função. Rio de Janeiro: Guanabara Koogan; 2001. p.24-49.

56. TRICHILIS A, WROBLEWSKI J. Expression of p53 and hsp70 in relation to apoptosis during Meckel's cartilage development in the mouse. Anat Embryol. 1997 Aug;196(2):107-13.

57. VAN DER WOUDE A. Fistula labii inferioris congenital and its association with cleft lip and palate. Am J Hum Genet. 1954 6:244-56.

58. VIEIRA AR, ROMITTI PA, ORIOLI IM, CASTILLA EE. Complex segregation analysis of 1,792 cleft lip and palate families in South America: 1967-1997. Pesqui Odontol Bras. 2003 Abr-Jun;17(2):161-5. 
59. VIEIRA AR, ORIOLI IM, CASTILA BB, COOPER MB, MARAZITA ML, MURRAY JC. MSX1 and TGFß3 contribute to clefting in South América. J Dent Res. 2003 Apr;82:289-92.

60. WARBRICK JG, McINTYRE JR, FERGUSON AG. Remarks on the aetiology of congenital bilateral fistulae of the lower lip. Br J Plast Surg. 1952;4:254-262.

61. WATANABE Y, IGAKU-HAKUSHI, OTAKE M, TOMIDA K. Congenital fistulas of the lower lip; report of five cases with special reference to the etiology. Oral Surg Oral Med Oral Pathol. 1951 Jun;4(6):709-22.

62. WESSELS MW, BROOKS AS, HOOGEBOOM J, NIERMEIJER MF, WILLEMS PJ. Kabuki syndrome: a review study of three hundred patients. Clin Dysmorphol. 2002 Apr;11(2):95-102.

63. WIENKER TF, HUDEK G, BISSBORT S, MAYEROVA A, MAUFF G, BENDER K. Linkage studies in a pedigree with Van der Woude syndrome. J Med Genet. 1987 Mar;24(3):160-2.

64. WONG FK, KARSTEN A, LARSON O, HUGGARE J, HAGBERG C, LARSSON C, et al. Clinical and genetic studies of Van der Woude syndrome in Sweden. Acta Odontol Scand. 1999 Apr;57(2):72-6.

65. XU X, HAN J, ITO Y, BRINGAS PJR, URATA MM, CHAI Y. Cell autonomous requirement for Tgfbr2 in the disappearance of medial edge epithelium during palatal fusion. Dev Biol. 2006 Sept;297(1):238-48.

66. ZHANG Z, SONG Y, ZHAO X, ZHANG X, FERMIN C, CHEN Y. Rescue of cleft palate in Msx1-deficient mice by transgenic Bmp4 reveals a network of BMP and Shh signaling in the regulation of mammalian palatogenesis. Development. 2002 Sept;129(17):4135-46.

67. ZUCCHERO TM, COOPER ME, MAHER BS, DAACK-HIRSCH S, NEPOMUCENO B, RIBEIRO L, et al. Interferon regulatory factor 6 (IRF6) gene variants and the risk of isolated cleft lip or palate. N Engl J Med. 2004 Aug 19;351(8):769-80. 
Abstract 


\section{CLINICAL, RADIOGRAPHIC AND MOLECULAR CHARACTERIZATION OF THE VAN DER WOUDE SYNDROME}

\section{ABSTRACT}

The Van der Woude syndrome (VWS) is characterized by the presence of congenital lower lip pits associated or not to cleft lip and/or palate. This disorder is the most common syndrome affecting patients with cleft lip and palate; despite of that, it is underdiagnosed. After DNA sequencing in 2001, there was an increase in the interest and development of studies on Human Molecular Genetics. In 2002, investigators identified the gene IRF6 on chromosome 1 as being responsible for the VWS. The present study comprised analysis of records of patients with VWS registered at the Hospital for Rehabilitation of Craniofacial Anomalies - HRAC - USP, as well as their first-degree relatives with cleft lip and/or palate without lip pits, adding up to 22 patients. Analysis comprised clinical and radiographic examinations, anthropometric measurements, salivary flow rate and genealogy of all patients. The results were compared with data on genetic and molecular investigations conducted in the $\mathrm{PhD}$ thesis of LIMA (2005). The oral findings in the present sample are very common in the phenotype of VWS, since $68.20 \%$ of patients had some type of developmental dental anomaly, and agenesis of at least one tooth was observed in $45.45 \%$ of patients. Therefore, dental professionals play a fundamental role in the diagnosis, oral examination and treatment of patients with VWS.

Descriptors: Syndrome, Investigation in Genetics, Mutation, Tooth agenesis, Anomalies. 